\title{
Canon Shortfalls and the Virtues of Political Branch Interpretive Assets
}

\author{
James J. Brudney†
}

\section{INTRODUCTION}

As a legislation scholar, Philip Frickey was present at the creation. ${ }^{1}$ Along with his coauthor William Eskridge, Frickey reconceptualized the field of legislation and statutory interpretation. In doing so, he opened the door to an unparalleled period of inquiry and debate about the meaning of statutes, among both judges and academics. The Eskridge and Frickey casebook, published in $1988,{ }^{2}$ was justly hailed by Judge Richard Posner as having "done for legislation what Hart and Sacks did for legal process, or Hart and Wechsler for federal courts: it has demonstrated the existence of a subject.",3

Over the ensuing two decades, Frickey has been at once a major contributor to and an essential chronicler of developments in this field. ${ }^{4} \mathrm{~A}$

Copyright $\odot 2010$ California Law Review, Inc. California Law Review, Inc. (CLR) is a California nonprofit corporation. CLR and the authors are solely responsible for the content of their publications.

$\dagger$ Newton D. Baker-Baker \& Hostetler Chair in Law, The Ohio State University Moritz College of Law. I am grateful to Bill Eskridge and Steve Huefner for valuable comments on an earlier draft, to Melanie Oberlin for extraordinary research assistance, and to Jennifer Pursell for excellent secretarial support. The Moritz College of Law contributed generous financial assistance.

1. See John Bartlett, Familiar Quotations 128 (14th ed. 1968) ("Had I been present at the creation, I would have given some useful hints for the better ordering of the universe." Alfonso X (The Wise) (1221-1284)).

2. William N. Eskridge, Jr. \& Philip P. Frickey, Cases and Materials on Legislation (1988) [hereinafter CASEBook]. The Casebook is now in its fourth edition, with Elizabeth Garrett as an additional coauthor. Page references in this Essay are to the fourth edition, published in 2007.

3. Richard A. Posner, Book Review, 74 VA. L. Rev. 1567, 1571 (1988). Posner's glowing review also described the casebook as "far and away the best set of teaching materials on the subject of legislation that has ever been published" and as having "the potential to alter the law school curriculum." Id. at 1567. Posner did express mild disappointment at the authors' omission of certain passages from Aristotle, Nietzsche, and Wittgenstein, among others, notwithstanding the laudable overall treatment of theoretical approaches to interpretation. Id. at 1570 \& n. 4 .

4. See, e.g., Philip P. Frickey, Interpretive-Regime Change, 38 Loy. L.A. L. REv. 1971 (2005) [hereinafter Frickey, Interpretive-Regime Change]; Philip P. Frickey, Revisiting the Revival of Theory in Statutory Interpretation: A Lecture in Honor of Irving Younger, 84 MinN. L. Rev. 199 (1999) [hereinafter, Frickey, Revisiting the Revival]; Philip P. Frickey, From the Big 
hallmark of his scholarship has been an appreciation for complexity-for the tensions and convergences between theory and practice in statutory interpretation, and for the historical, institutional, and normative perspectives that judges, lawyers, social scientists, and legal academics bring to the interpretive enterprise. ${ }^{5}$

This Essay examines Frickey's treatment of the canons of construction, an aspect of his attentiveness to complexity. Two general themes emerge from the discussion and analysis in a number of Frickey's articles. One is his effort to unmask: he critically assesses descriptive claims that the canons promote more predictable construction of statutes, as well as normative claims that they foster more neutral policy outcomes. The second theme is Frickey's effort to understand and justify: he views the canons as performing a useful role for the judiciary as an institution in certain settings. Ultimately, Frickey defends the canons as an institutional resource, but in more reserved terms than those offered by canon enthusiasts. ${ }^{6}$

The Essay then expands upon Frickey's concerns by presenting two sets of observations that focus on how the canons differ from legislative history and agency guidance. Based on these observations, the Essay suggests that the canons should be subordinated to interpretive resources produced by the institutions of Congress and the executive.

My first set of observations involves legitimacy and stems from our separation-of-powers understanding that in the statutory domain, federal courts are expected to act as agents of the politically accountable branches. ${ }^{7}$ Article I of the Constitution authorizes Congress to organize itself in fulfillment of its legislative mission ${ }^{8}$ and requires Congress to publish a record of its legislative proceedings.' Although the Founders did not anticipate judicial review of

Sleep to the Big Heat: The Revival of Theory in Statutory Interpretation, 77 MinN. L. REv. 241 (1992).

5. See, e.g., supra note 4; Philip P. Frickey, Getting from Joe to Gene (McCarthy): The Avoidance Canon, Legal Process Theory, and Narrowing Statutory Interpretation in the Early Warren Court, 93 CALIF. L. REv. 397 (2005) [hereinafter Frickey, Getting from Joe to Gene]; Philip P. Frickey \& Steven S. Smith, Judicial Review, The Congressional Process, and the Federalism Cases: An Interdisciplinary Critique, 111 YALE L.J. 1707 (2002); Philip P. Frickey, Faithful Interpretation, 73 WASH. U. L.Q. 1085 (1995) [hereinafter Frickey, Faithful Interpretation]; see also Frickey, infra notes 16, 37, 50, 52, 100, 102, and 103.

6. See generally ANTONin Scalia, A Matter of Interpretation: FedERAL Courts and The LAW 25-29 (1997); CASS R. Sunstein, AFTER the Rights Revolution: Reconceiving the Regulatory State 147-57 (1990); David L. Shapiro, Continuity and Change in Statutory Interpretation, 67 N.Y.U. L. REV. 921, 943-45 (1992).

7. See, e.g., Frank B. Cross, The Theory and Practice of Statutory INTERPRETATION 3 (2009); Chevron U.S.A., Inc. v. Natural Res. Def. Council, Inc., 467 U.S. 837 , 865-66 (1984); W. Va. Univ. Hosps., Inc. v. Casey, 499 U.S. 83, 112-16 (1991) (Stevens, J., dissenting).

8. See U.S. CONST. art. I, $\S 5$, cl. 2 ("Each House may determine the Rules of its Proceedings ....").

9. See U.S. ConST. art. I, $\S 5$, cl. 3 ("Each House shall keep a Journal of its Proceedings, 
statutes as that process has developed, their Article I contribution helped create two notable innovations in legislative design that are relevant to how courts should approach statutory interpretation. These design innovations, dating from the earliest Congresses, were the determination to favor detailed public reporting of floor debates and the decision to create permanent standing committees that produced oral and then written committee reports. ${ }^{10}$ Taken together, these innovations led to the development of legislative history as a means of informing and persuading members of Congress regarding the bills on which they were to vote.

Canons lack any comparable constitutional foundation. As creations of the judicial branch, their contribution was not anticipated within the constitutionally prescribed structure of federal lawmaking. Nor-unlike legislative history-was their functional role in the lawmaking process recognized by the early Congresses. In addition, current evidence suggests that-again unlike legislative history-the canons are largely unknown to or ignored by the legislators and staff who draft, negotiate, and vote on statutory text. ${ }^{11}$ Because the canons' interpretive validity is fundamentally disconnected from the Article I lawmaking structure and the realities of the legislative process, there is reason to question whether courts should value canons to the same extent as interpretive resources produced by Congress. ${ }^{12}$

My second set of observations involves reliability. The Court's interpretive rubric has given rise to a relatively objective internal hierarchy for contextual resources produced by Congress and also by the executive branch. Certain types of legislative history and agency directives are presumptively valued more than others. ${ }^{13}$ Judicial deviations from this hierarchy tend to be accompanied by some explanation for the departure. ${ }^{14}$ Importantly, the priorities established for legislative history and agency directives flow from how Congress and the executive function, both in terms of relying on authoritative sources of expertise and valuing deliberative processes.

and from time to time publish the same....").

10. See infra, Part II.B.1-2.

11. See infra, Part II.B.4.

12. Cf. Einer Elhauge, Statutory Default Rules 151-67 (2008) (discussing why canons are a third-order resource, to be invoked only when enactable preferences cannot be inferred and enactor preferences cannot be estimated). Given assigned word limitations, this Essay does not explore comparable ways in which interpretive resources produced by the executive branch may also be constitutionally grounded in the lawmaking process. For a preliminary suggestion that the Founders anticipated an interpretive role for agency officials, see infra note 160. For in-depth discussion of agency approaches to statutory interpretation between 1787 and the Civil War, see Jerry L. Mashaw \& Avi Perry, Administrative Statutory Interpretation in the Antebellum Republic, 2009 Mich. ST. L. Rev. 7 (2009) and Jerry L. Mashaw, Recovering American Administrative Law: Federalist Foundations, 1787-1801, 115 YALE L.J. 1256 (2006).

13. See infra Parts II.C.1-2.

14. See id. 
By contrast, there is no recognized ordering of authority within the canonical universe. The Court has never developed rules for harmonizing or prioritizing among the scores of existing canons, many of which the Court has created in recent decades. ${ }^{15}$ One language canon may trump another, one substantive canon may displace another, and a language canon may be deemed subservient to a substantive canon in one instance and dominant in the next. This lack of an intelligible framework for ordering the canons renders them distinctly more susceptible to judicial manipulation than other interpretive resources.

Part I of this Essay discusses Frickey's treatment of the canons. Part II builds on Frickey's insights to raise and develop my comparative institutional observations. These observations suggest subordinating the canons to other interpretive resources that are at once more legitimately grounded in the lawmaking process and more genuinely objective.

I

\section{PROFESSOR FRICKEY AND THE CANONS}

Although this Part examines Frickey's treatment of the canons from a doctrinal rather than a chronological perspective, his approach has evolved over two decades. Frickey initially focused more on whether the canons promote rule-of-law values, ${ }^{16}$ whereas in later writings he addressed the canons' role in furthering institutional, strategic behavior by courts. ${ }^{17}$ Frickey has always expressed a degree of skepticism about claims made by canons proponents, but he now seems more ambivalent in normative terms than he was earlier in his career.

\section{A. Frickey's Skepticism About the Canons}

\section{Language Canons and Predictability}

Language canons are generally justified as background, interpretive norms that embody conventional usage-c"plausible or even irresistible judgments about how words should ordinarily be understood."18 Such judgments are supposed to help courts to determine why a statutory provision includes certain words configured in a particular order, or what relationship exists between the

15. See CASEBOOK, supra note 2, at app. B (listing more than one hundred substantive canons used by Rehnquist Court); infra Part II.C.3 (discussing absence of hierarchy among the canons).

16. See William N. Eskridge \& Philip Frickey, The Supreme Court, 1993 Term Foreword: Law as Equilibrium, 108 HARv. L. REv. 27, 65-67 (1994); Frickey, Faithful Interpretation, supra note 5, at 1090-91; Frickey, Revisiting the Revival, supra note 4, at 206-07.

17. See Frickey \& Smith, supra note 5, at 1714-16; Frickey, Interpretative-Regime Change, supra note 4, at 1986-92; Frickey, Getting from Joe to Gene, supra note 5, at 450-61.

18. SUNSTEIN, supra note 6 , at 150. 
included words and identical or different language found in other parts of the same or perhaps separate statutes. ${ }^{19}$ Canon supporters maintain that these linguistic judgments are presumptively shared by those who regularly draft and approve legislative text ${ }^{20}$ and also by those who seek to conform their conduct to directives set forth in that text. ${ }^{21}$ Insofar as the legislative community and the general public invoke considerations of ordinary meaning when enacting or complying with statutes, judicial reliance on such conventional usages is said to promote greater predictability in statutory interpretation.

Professor Frickey is not persuaded. In his succinct essay titled Faithful Interpretation, ${ }^{22}$ Frickey maintains that the concept of ordinary or conventional meaning rests on the dubious assumption that statutes are or can be largely selfdefining. ${ }^{23}$ Although predictability and clarity are values prized as part of the interpretive enterprise, they can never be the whole story. Because statutes are "instruments of practical contextual communication," faithful interpretation requires that courts adjust the scope and precision of rights or privileges conferred-or duties imposed-in light of novel or unforeseeable circumstances ${ }^{24}$ Further, given that statutes also are "instruments of ... social governance," faithful interpretation requires that courts remain sensitive to extrinsic public law values, including those emanating from the Constitution. ${ }^{25}$

Frickey's insistence that statutes be construed as far more than linguistic puzzles comports with the perspectives of key players in the lawmaking process such as members of Congress, their staffs, and executive branch participants. Neither the legislators who enact statutes nor the citizens and businesses that seek to abide by them rely primarily on their own linguistic judgments embodying notions of ordinary or conventional meaning. Most public laws in our complex regulatory state are written to be interpreted and understood by legal experts rather than laypersons. ${ }^{26}$

19. See generally CASEBOOK, supra note 2, app. B at 19-23 (discussing inter alia the canons of noscitur a sociis and expressio unius, the Whole Act rule, the presumption against redundancy, and the presumption of statutory consistency with respect to the same or similar terms).

20. See Green v. Bock Laundry Mach. Co., 490 U.S. 504, 528 (1989) (Scalia, J., concurring) (interpreting inconclusive text by looking for "which meaning is [the] most in accord with context and ordinary usage, and thus most likely to have been understood by the whole Congress which voted on the words of the statute") (emphasis in original).

21. See Frank H. Easterbrook, The Role of Original Intent in Statutory Construction, 11 HARV. J.L. \& PUB. POL'Y. 59, 65 (1988) (concluding that court's role is to "look at the statutory structure and hear the words as they would sound in the mind of a skilled, objectively reasonable user of words"); see generally, Nix v. Heddon, 149 U.S. 304, 306-07 (1893) (concluding that "in the common language of the people," tomatoes were a covered vegetable, not an exempt fruit, under 1883 Tariff Act).

22. See Frickey, Faithful Interpretation, supra note 5.

23. See id.

24. Id. at 1089 .

25. Id.

26. See generally Robert K. Rasmussen, Why Linguistics?, 73 Wash U. L.Q. 1047, 1051- 
An example from the National Labor Relations Act illustrates this point. When Congress declares that employers may not "interfere with, restrain, or coerce" employees' efforts to join or support unions, ${ }^{27}$ it does so anticipating that such statutory commands will acquire meaning through diagnostic and prescriptive analyses by lawyers, agency regulators, and judges. There is no conventional usage or ordinary understanding that explains why a supervisor questioning an employee about her union sympathies has not "interfered",28 with the employee's right to organize, or why a manager convening a mandatory meeting during work hours to predict-or even misrepresent-the risks associated with unions has not "restrained" or "coerced"29 employees in their exercise of that right. The statutory prohibitions on employer conduct have accrued content through decades of lawyer-directed practical applications. These applications include advising management $e x$ ante on how to encourage workers to reject a union without committing unlawful interference or coercion, and advocating to agencies and courts ex post on whether what workers experienced amounted to coercion or restraint, or instead was simply a form of vigorous employer speech protected under the NLRA and arguably sheltered by the First Amendment. ${ }^{30}$

Stepping back, citizens and businesses do not generally expect to review statutory language in order to understand their rights and responsibilities under the law. In our modern regulatory state, individuals and corporations consult lawyers to help them derive meaning from statutory text. Even for criminal statutes, something of a special case, ${ }^{31}$ criminal lawyers effectively serve as translators ex ante and as monitors ex post. An individual who pays off a large gambling debt by purchasing cashiers' checks from a series of banks does not himself consult the federal criminal code to determine if he has "willfully violat[ed]" the anti-structuring provisions of federal money-laundering law; he asks a lawyer for expert advice. ${ }^{32}$

54 (1995); Stephen F. Ross, The Limited Relevance of Plain Meaning, 73 WASH. U. L.Q. 1057, $1057-58(1995)$.

27. 29 U.S.C. § $158(a)(1)(2006)$.

28. See The Developing LabOr Law 171-73 (John E. Higgins Jr. ed., 5th ed. 2006) (discussing NLRB's totality-of-the-circumstances approach when reviewing employer interrogation of individual employees).

29. See Livingston Shirt Corp., 107 N.L.R.B 400, 405-06 (1953) (allowing employer captive audience speeches); see also NLRB v. Gissel Packing Co., 315 U.S. 595, 618 (1969) (allowing employer predictions but not threats); Midland Nat'l Life Ins. Co., 263 N.L.R.B. 127, 133 (1982) (allowing employer misrepresentations).

30. See Thomas v. Collins, 323 U.S. 516, 537-38 (1945) (discussing difference between employer persuasion and coercion as First Amendment matter); 29 U.S.C. $\S$ 158(c) (2006) (identifying difference as statutory matter).

31. The severity of punishment attached to criminal statutes leaves citizens more vulnerable if the prohibitions of the law are not adequately clear and understandable. See Muscarello v. United States, 524 U.S. 125, 148-50 (1998) (Ginsburg, J., dissenting).

32. See generally Ratzlaf v. United States, 510 U.S. 135 (1994). 
As Professors Stephen Ross and Edward Rubin have observed, most federal statutes are not designed to be read by citizens at large, but rather by a small community of lawyers, regulators, and individuals or firms subject to rules drafted by lawyers. ${ }^{33}$ This narrower group of specialists develops the meaning of statutory prohibitions, directives, or entitlements in light of the evolving circumstances and extrinsic public-law values that Professor Frickey has referenced. ${ }^{34}$ Frickey advises that language canon proponents should be wary of simplification: the legal interpretive community's attribution of meaning to a statute is both "complex and normatively driven." 35 It is therefore neither candid nor constructive to assert that legal interpretation relies in any conclusive or mechanical way on notions of conventional usage or ordinary meaning. ${ }^{36}$ Given that such notions have little impact in constraining judges' ability to make pragmatic or normative choices, it also is not overly persuasive to maintain that reliance on language canons enhances predictability or judicial objectivity. ${ }^{37}$ My coauthored empirical study of Supreme Court decisions invoking language canons over a thirty-five-year period supports Frickey's skepticism on these points. ${ }^{38}$

\section{Substantive Canons and Neutrality}

Substantive canons are grounded not in judgments about the conventional understanding of language, but in an array of judicially generated policy concerns. Among more than one hundred such canons set forth in the latest edition of the Casebook are norms or presumptions regarding how statutory text should be harmonized with judicially identified constitutional priorities, ${ }^{39}$ judicially perceived statutory objectives, ${ }^{40}$ or pre-enactment common law practices. ${ }^{41}$ Like their linguistic cousins, substantive canons are justified

33. See Ross, supra note 26, at 1057; Edward L. Rubin, Law and Legislation in the Administrative State, 89 ColUM. L. REv. 369, 381, 383 (1989).

34. See Frickey, Faithful Interpretation, supra note 5, at 1085; text accompanying supra notes $24-25$.

35. See Frickey, Faithful Interpretation, supra note 5, at 1094.

36. See id.; RICHARD A. POSNER, How Judges THINK 193 (2008).

37. See generally Philip P. Frickey, Legislative Processes and Products, 46 J. LEGAL EDUC. 469, 473-74 (1996).

38. See James J. Brudney \& Corey Ditslear, Canons of Construction and the Elusive Quest for Neutral Reasoning, 58 VAND. L. REV. 1, 93-102 (2005).

39. See CASEBOOK, supra note 2, app. B at 29-33 (discussing inter alia the presumption against federal preemption of traditional state regulation, the presumption against interpretations that would jeopardize a statute's constitutionality, and the rule of lenity).

40. See id. at 36-41 (discussing inter alia the presumption against repeals by implication, the strict construction of statutes authorizing appeals, and the presumption that each side bears its own costs in adjudications).

41. See id. at 34-35 (discussing inter alia the presumption against extraterritorial application of U.S. law, the rule against implied waivers of U.S. sovereign immunity, and the presumption favoring common law usage where Congress employs words or concepts with wellsettled common law traditions). 
primarily by reference to imputed congressional understanding. For instance, when the text is inconclusive, Congress is viewed as preferring that meaning "most compatible with the surrounding body of law into which the provision must be integrated-a compatibility which, by a benign fiction, we assume Congress always has in mind." 42 Thus, the Supreme Court assumes that Congress generally prefers exemptions to the Internal Revenue Code to be narrowly construed, ${ }^{43}$ believes labor-management arbitration agreements should be enforced, ${ }^{44}$ and wants states' core sovereign authority preserved unless it imposes limits on such authority in unmistakably clear textual terms. ${ }^{45}$

Professor Frickey unmasks this seemingly benign fiction. He identifies two principal ways - the creation of new canons, and drift in the meaning of the canons - by which the Court's use of substantive canons undermines claims of neutrality as well as predictability.

With respect to the Court's tendency to create new substantive canons, a judicially expressed policy preference should not in theory become a canon until it is firmly rooted and widely recognized. ${ }^{46}$ Yet the sheer volume of substantive canons relied on by the Court in recent times raises questions as to whether they are stable, judicially entrenched norms. The Casebook lists 105 substantive policy canons invoked by the Rehnquist Court from 1986 to 2006, compared with 28 language canons invoked during the same period. ${ }^{47}$ Moreover, as Frickey observes, the Court may announce a new policy presumption and shortly thereafter reference this presumption as an established substantive canon based simply on its prior decision. ${ }^{48}$

Many of the substantive canons invoked since the mid-1980s narrow the scope or impact of text enacted by Congress, assigning broader authority and

42. Green v. Bock Laundry Mach. Co., 490 U.S. 504, 528 (1989) (Scalia, J., concurring) (emphasis added).

43. See United States v. Wells Fargo Bank, 485 U.S. 351, 354, 356 (1988).

44. See Nolde Bros. v. Local 358 Bakery Workers, 430 U.S. 243, 254-55 (1977)

45. See, e.g., Gregory v. Ashcroft, 501 U.S. 452, 460-67 (1991) (holding that Congress failed to subject appointed state judges to mandatory retirement under Age Discrimination in Employment Act); Will v. Mich. Dept. of State Police, 491 U.S. 58, 65-68 (1989) (holding that Congress failed to subject states to liability as "persons" under section 1983 of the 1871 Civil Rights Act).

46. See Kent Greenawalt, Statutory Interpretation: 20 Questions 211 (1999); Richard L. Hasen, The Democracy Canon, 62 Stan. L. Rev. 69, $92-94$ (2009).

47. See CASEBOOK, supra note 2, app. B at 19-23 (listing language canons with case citations); id. at 29-41 (listing substantive canons with case citations). In addition to these 105 separate substantive canons, the Casebook lists 21 more Rehnquist Court policy canons derived from statutory sources: 12 related to considerations of statutory continuity and 9 referring to extrinsic legislative sources, principally legislative history. See id. at 25-28.

48. See Frickey, Interpretive-Regime Change, supra note 4, at 1990-91 (describing the Court's two-step creation of a canon that "a party contending that legislative action changed settled law has the burden of showing that the legislature intended such a change," quoting Green v. Bock Laundry Mach. Co., 490 U.S. 504, 521 (1989)). See also CASEBOoK, supra note 2, at 1213 (suggesting that Court is in process of canonizing a presumption against reading statutory delegations broadly, based on decisions in 1994 and 2000). 
discretion to the states, ${ }^{49}$ the executive branch, ${ }^{50}$ and the laws of other nations. ${ }^{51}$ The Court has been especially forceful in announcing new presumptions and clear statement rules that elevate and enforce federalism values. ${ }^{52}$ As Frickey points out, the Court's canonical preferences for state sovereignty over national regulation, and also for private ordering over government regulation, are hardly policy-neutral; rather, they qualify as troubling forms of countermajoritarian judicial activism. $^{53}$

In addition to this normative concern, the Court's proliferation of substantive canons affects the orderly and integrated elaboration of statutory law. Canonizing various policy preferences obviates the need to develop and defend judicial reasoning through detailed analysis of textual meaning, legislative purpose, or prior precedent. Frickey's description of the substantive canons as "techniques of judicial evasion" assuming, arguendo, that Congress generally wants tax exemptions to be narrowly construed or states' core sovereign functions to be preserved, the Justices' reliance on such presumptions allows them to minimize in-depth inquiry as to what Congress actually meant to accomplish through a particular exemption or a specific limitation on states' authority. ${ }^{55}$

A further consequence of proliferating substantive canons that relates to orderly elaboration of the law is the Court's decreased willingness to address the challenges posed by updated statutory text and unforeseen factual circumstances. Congress typically revisits and modifies its major regulatory schemes over several decades. In doing so, it adjusts various protections and prohibitions in light of intervening agency or court decisions, the advent of new statutes in related areas, and changed social or economic conditions. ${ }^{56}$ Yet by

49. See, e.g., Raygor v. Regents of Univ. of Minn. 534 U.S. 533, 543-44 (2002); BFP v. Resolution Trust Corp., 511 U.S. 531, 543-45 (1994); Gregory v. Ashcroft, 501 U.S. 452, 460-64 (1991).

50. See, e.g., Lincoln v. Vigil, 508 U.S. 182, 190-92 (1993); Franklin v. Massachusetts, 505 U.S. 788, 800-01 (1991); William N. Eskridge, Jr. \& Philip P. Frickey, Quasi-Constitutional Law: Clear Statement Rules as Constitutional Lawmaking, 45 VAND. L. REv. 593, 642-44 (1992).

51. See, e.g., Microsoft Corp. v. AT\&T, 550 U.S. 437, 454-56 (2007); F. HoffmanLaRoche Ltd. v. Empagran S.A., 542 U.S. 155, 164 (2004); EEOC v. Arabian Am. Oil Co. 499 U.S. 244, 248 (1991).

52. See Philip P. Frickey, Interpretation on the Borderline: Constitution, Canons, Direct Democracy, 1 N.Y.U. J. LEGIS. \& PUB. POL'Y 105, 128-31 (1997) [hereinafter Frickey, Interpretation on the Borderline]; Eskridge \& Frickey, supra note 50, at 619-28.

53. See Eskridge \& Frickey, supra note 50, at 640-44.

54. Frickey, Interpretive-Regime Change, supra note 4, at 1988.

55. See James J. Brudney \& Corey Ditslear, The Warp and Woof of Statutory Interpretation: Comparing Supreme Court Approaches in Tax Law and Workplace Law, 58 DuKE L.J. 1231, 1295-98 (2009) (discussing Court's use of tax-based substantive canons to frame and simplify judicial analysis).

56. Congress amended Title VII of the 1964 Civil Rights Act in 1972, 1978, and 1991, and it has modified the 1933 and 1934 securities laws on several recent occasions as well. See generally Michael A. Perrino, Fraud and Federalism: Preempting Private State Securities Fraud Causes of Action, 50 STAN. L. REv. 273 (1998) (discussing 1995 Private Securities Litigation 
invoking policy presumptions as a way of framing and simplifying their analyses at a given statutory moment, the Justices make it less likely that such subsequent legal or factual developments will be thoroughly considered. ${ }^{57}$

As Frickey recognizes, one possible justification for the substantive canons' lack of interpretive neutrality and their evasive tendencies is that the Court's injection of its own policy norms helps make statutory interpretation more predictable. ${ }^{58}$ If the substantive canons are regularly invoked and consistently applied, then the Court's methodology should be transparent enough so that legislators, lower courts, and lawyers can conduct their own business "with a reasonable degree of certainty about [the] likely judicial reception down the road." 59 But, this is where Frickey's second concern comes into play: even established substantive canons undergo subtle drifts or sudden shifts in meaning over time. ${ }^{60}$

In terms of drift, the Court since the late 1980s has often declared that Congress must be reasonably clear when it seeks to define criminal activity, ${ }^{61}$ to assert extraterritorial jurisdiction, ${ }^{62}$ or to interfere with traditional or historical state functions. ${ }^{63}$ The Court's declarations, however, have not resulted in clarity or predictability from one decision to the next. The rule of lenity, prescribing that ambiguity in a penal statute should be resolved in favor of the defendant, may serve as a front-end presumption effectively shaping the interpretive process, or merely as a tiebreaker at the back end of that process. ${ }^{64}$

Reform Act); David M. Levine \& Adam C. Pritchard, The Securities Litigation Uniform Standards Act of 1998: The Sun Sets on California's Blue Sky Laws, 54 Bus. LAw. 1 (1998). Amendments to the Internal Revenue code are even more frequent. See Richard Gershon, A Student's Guide to THE INTERnal Revenue Code \& 1.02 (4th ed. 1999) (discussing Congress's regular amendments to the 1986 code, including "fairly major changes" in 1991, 1993, and 1996).

57. See, e.g., Gregory v. Ashcroft, 501 U.S. 452, 477-78 (1991) (White, J., dissenting in part) (criticizing majority's use of super strong clear statement rule protecting state's sovereign authority as a way to limit the development of Court's constitutional precedent in this area); EEOC v. Arabian Am. Oil Co., 499 U.S. 244, 260-66, 278 (1991) (Marshall, J., dissenting) (criticizing majority's use of presumption against extraterritoriality as a barrier to considering legislative history sources that indicate how Congress meant to protect employee interests).

58. See Eskridge \& Frickey, supra note 16, at 66-67.

59. Frickey, Interpretive-Regime Change, supra note 4, at 1981.

60. See id. at 1983-84, 1989-90; Eskridge \& Frickey, supra note 50, at 635-36.

61. See, e.g., Arthur Anderson LLP v. United States, 544 U.S. 696, 703-06 (2005); Cleveland v. United States, 531 U.S. 12, 24-25 (2000); United States v. Kominski, 487 U.S. 931, 949-52 (1988).

62. See, e.g., Microsoft Corp. v. AT\&T, 550 U.S. 437, 454-56 (2007); EEOC v. Arabian Am. Oil Co., 499 U.S. 244, 248 (1991); Argentine Republic v. Amerada Hess Shipping Corp., 488 U.S. $428,440-41$ (1989).

63. See, e.g., Bates v. Dow Agrosciences LLC, 544 U.S. 431, 449 (2005); Hawaiian Airlines v. Norris, 512 U.S. 246, 252 (1994); California v. ARC Am. Corp., 490 U.S. 93, 100-01 (1989).

64. See Muscarello v. United States, 524 U.S. 125, 138-39 (1998) (Breyer, J.) (using the rule of lenity as a tiebreaker); id. at 148-50 (Ginsburg, J., dissenting) (concluding it is a front-end presumption); Frickey, Interpretive-Regime Change, supra note 4, at 1990. This divergence in 
Similarly, the rule disfavoring extraterritorial jurisdiction may operate as a presumption that can be overcome by the cogent force of legislative history and other contextual evidence of congressional will, or as a virtually irrebuttable clear statement rule. ${ }^{65}$ And the Court's admonition against federal preemption of traditional state regulation is distinguished just as often as it is followed. ${ }^{66}$

The proposition that Congress places a high priority on the goal of achieving clarity in statutory text is at a minimum contestable. ${ }^{67}$ But even if Congress regards such clarity as desirable, the Court's divergent understandings as to how its policy presumptions should be weighted, and its inconsistent application of these presumptions, belie the notion that substantive canons can effectively channel the congressional drafting enterprise. ${ }^{68}$

While canon drift poses a threat to predictability, more dramatic shifts in canon meaning give rise to additional concerns about neutrality. When the Court suddenly elevates a weak canon into a clear statement rule, it effectively penalizes Congress for having failed to foresee years earlier how the Court's preferences were likely to change. 69 This "bait-and-switch" tactic enables the Court to disrespect Congress's prior policy judgments without acknowledging that it is doing so. ${ }^{70}$ Frickey points out how this has occurred with regard to Congress's approach to abrogating states' immunity to suit in federal court. ${ }^{71}$ The Court has imposed clear statement rules on text enacted in a very different era of judicial expectations to frustrate other congressional policy preferences as well. $^{72}$

views may be expressed within the opinions of a single Justice. Compare Muscarello v. United States, 524 U.S. 125, 148-50 (1998) (Ginsburg, J., dissenting), with United States v. Hayes, 129 S.Ct. 1079, 1088-89 (2009) (Ginsburg, J., majority).

65. See EEOC v. Arabian Am. Oil Co., 499 U.S. 244, 260-66, 278 (1991) (Rehnquist, J., majority, concluding it is a clear statement rule); $i d$. at 260-66 (Marshall, J., dissenting) (concluding it is a presumption).

66. See, e.g., Note, New Evidence on the Presumption Against Preemption: An Empirical Study of Congressional Responses to Supreme Court Preemption Decisions, 120 Harv. L. Rev. 1604, 1612-13 (2007) (reporting that from 1983 to 2004, the "Court decided 127 cases involving federal preemption of state law": state law held not preempted 59 times, fully preempted 59 times, and partly preempted 9 times); Brudney \& Ditslear, supra note 38, at $106 \&$ nn.438-39 (listing ERISA decisions between 1989 and 2002 in which anti-preemption rule was relied on and others in which it was distinguished or disregarded).

67. See, e.g., Victoria F. Nourse \& Jane S. Schacter, The Politics of Legislative Drafting: A Congressional Case Study, 77 N.Y.U. L. Rev. 575, 600-05, 614-16 (2002); Stephen Breyer, On the Uses of Legislative History in Interpreting Statutes, 65 S. CAL. L. Rev. 845, 870-71 (1992); see also Cheryl Boudreau et al., What Statutes Mean: Interpretive Lessons from Positive Theories of Communication and Legislation, 44 SAN DiEgo L. Rev. 957, 967-73 (2007) (contending that statutory text is a form of compressed policy instruction and legislative history enables courts to expand that instruction based on the meanings contemplated by those who transmitted the instructions).

68. See Frickey, Interpretive-Regime Change, supra note 4, at 1990.

69. See generally Brudney \& Ditslear, supra note 38 , at 106-07.

70. See Frickey, supra note 37, at 474 n.29; CASEBOOK, supra note 2, at 939-41.

71. See Frickey, Interpretive-Regime Change, supra note 4, at 1983-84.

72. See Gregory v. Ashcroft, 501 U.S. 452 (1991) (thwarting Congress's 1974 
Moreover, although the Rehnquist Court's canonically-induced shifts were not explained or justified as constitutional pronouncements, they turn out to be comparably difficult to revisit by means of congressional override. Frickey observes that such overrides would presumptively be sought to vindicate Congress's civil rights or worker protection preferences in an era of divided government. ${ }^{73}$ To overcome a conservative President on these matters, Congress would need the same two-thirds supermajorities in each house as is required for a constitutional amendment. ${ }^{74}$ Further, the enactability of a congressional override preference also depends on the legislative vehicle in which it would likely be packaged. ${ }^{75}$ For instance, statutes enacted in the 1970 s extending states' liability to their employees were not controversial when integrated as part of legislative packages aimed at combating workplace discrimination in general. ${ }^{76}$ But if the policy package presented to Congress were to focus primarily - if not exclusively - on exposing states to monetary liability, especially during austere economic times, then congressional approval would become far more of a challenge.

\section{B. Frickey's Limited Defense of the Canons on Institutional Grounds}

Although Frickey devotes considerable analytic attention to unmasking certain claims advanced by canon proponents, he is not prepared to dismiss the canons as an interpretive resource. Rather, he regards them as performing useful, albeit circumscribed, functions in a Court-created interpretive regime. Frickey's defense addresses the language canons' role in encouraging more efficient statutory drafting and the substantive canons' role in signaling the intensity of judicial policy preferences. ${ }^{77}$ In each instance, Frickey attempts to defend the canons' value by invoking the Court's institutional role relative to Congress.

determination to regulate states' sovereign authority); see also Solid Waste Agency v. Army Corps of Eng'rs, 531 U.S. 159, 172-74 (2001) (thwarting Congress's determination to regulate certain intrastate activities). See generally Ruth Colker \& James J. Brudney, Dissing Congress, 100 MiCH. L. REV. 80 (2001).

73. See Eskridge \& Frickey, supra note 50, at 635-39 (discussing four cases, decided during Republican presidencies, construing Fair Labor Standards Act, Civil Rights Act, and Education of the Handicapped Act).

74. See id. at 639.

75. See Elizabeth Garrett, Preferences, Laws, and Default Rules, 122 HaRv. L. Rev. 2104, 2132 (2009) (book review).

76. See, e.g., Equal Employment Opportunity Act of 1972, Pub. L. No. 92-261, § 2, 86 Stat. 103, 103 (1972) (conference report approved 62 to 10 in Senate, and 303 to 110 in House, 118 Cong. Rec. 7170, 7572-73 (1972)); Fair Labor Standards Amendment of 1974, Pub. L. No. 93-259, $\S 28,88$ Stat. 55, 74 (1974) (conference report approved 345 to 50 in House, and 71 to 19 in Senate, 120 Cong. Rec. 8605, 8769 (1974)); see also Americans with Disabilities Act of 1990, Pub. L. No. 101-336, $\S 101,104$ Stat. 327, 330 (1990) (conference report approved 377 to 28 in House, and 91 to 6 in Senate, 136 Cong. Rec. 17296-97, 17376 (1990)).

77. See Eskridge \& Frickey, supra note 16, at 65-71. 


\section{Encouraging Efficient Legislative Drafting}

In his coauthored Supreme Court Foreword, Frickey suggests that language canons can lower the cost of drafting statutes by establishing what are in effect rules of the road. ${ }^{78}$ Thus, for instance, if the Court regularly applies the expressio unius canon, legislative drafters will come to understand ex ante that when inserting a list of protected or prohibited activities they should either make the list exhaustive or add language specifying that the list is purely illustrative. ${ }^{79}$ Even if the expressio unius canon relies on an unrealistic vision of past legislators as omniscient drafters, a consistent judicial respect for this canon will encourage current and future legislators to be more careful when including lists in their statutory drafts. ${ }^{80}$

However, Frickey subsequently expresses two important reservations as to whether the canons really can make drafting more efficient. First, members of Congress generally do not care all that much about rules of the road. Successful legislative drafting typically requires collective action through negotiated agreement among three institutional players-the House, the Senate, and the President. ${ }^{81}$ It is a "competitive process of coalition-building, bargaining, and voting" that includes the resolution of intense conflicts of policy interests and priorities. ${ }^{82}$ In this highly pressurized consensus-driven setting, legislators and their staffs do not tend to rely on or seriously consider generalized rules of construction. ${ }^{83}$ Accordingly, when members draft a list of occupations exempted from statutory immigration controls, ${ }^{84}$ or of supervisory powers that preclude being protected under national labor laws, ${ }^{85}$ these lists are more likely to reflect a series of negotiations among sponsors and supporters, and less likely to involve close attention to judicial guidelines of clear drafting. ${ }^{86}$

78. See id. at 67.

79. See id.

80. See id. But cf. Richard A. Posner, Statutory Interpretation-in the Classroom and in the Courtroom, 50 U. CHI. L. REv. 800, 811 (1983) (arguing that lack of omniscience cannot be addressed, much less cured, through greater attention to rules of drafting, because the core reason behind this lack of omniscience is that text "necessarily is drafted in advance of, and with imperfect appreciation for the problems that will be encountered in, its application").

81. See Frickey \& Smith, supra note 5, at 1744-46.

82. Id. at 1745 .

83. See Nourse \& Schacter, supra note 67 , at $600-05,614-16$.

84. See Church of the Holy Trinity v. United States, 143 U.S. 457, 458-59, 462-65 (1892) (analyzing language and purpose of 1885 Immigration Act).

85. See NLRB v. Health Care \& Retirement Corp., 511 U.S. 571, 578-79, 587-88 (1994) (presenting conflicting interpretations of language and purpose of 1947 amendment to National Labor Relations Act).

86. See Nourse \& Schacter, supra note 67, at 614-16; William W. Buzbee, The OneCongress Fiction in Statutory Interpretation, 149 U. PA. L. REv. 171, 179, 190-92 (2000). 
Second, courts often disagree about how the rules of the road operate. ${ }^{87}$ This disagreement is not surprising given that Congress's regulatory schemes typically involve the accretion of successive enactments addressing new and overlapping issues over multiple decades. ${ }^{88}$ Such lawmaking developments tend to produce linguistic complexities that undermine canonical aspirations to avoid surplus phrases or maintain textual integrity. Accordingly, it is not surprising that thoughtful Justices frequently differ as to which interpretation truly promotes broader structural coherence, ${ }^{89}$ or best comports with inferences concerning particularized word choice or sentence structure. ${ }^{90}$ Even if Congress were to pay closer attention to language canons when drafting, legislators would be hard-pressed to find consistent guidance or encouragement from judicial applications of these canons.

Assuming the language canons cannot systemically encourage Congress to draft more efficiently, they may still assist courts in situational terms by deepening the interpretive inquiry. What Frickey calls "[p]erhaps the least ambitious defense" involves viewing these canons as a checklist of things for courts to consider, a "catalogue of contextual factors." they are subject to being questioned, challenged, or distinguished in light of other interpretive factors. ${ }^{92}$ The use of language canons to recognize and respond to arguments raised by lower courts, dissenting Justices, or nonprevailing parties effectively invites courts to consider additional sources of legislative meaning, which in turn enhances the shape and coherence of majority opinions. In short, language canons may contribute to the Court's

87. See Frickey, Revisiting the Revival, supra note 4, at 207-12 (doubting that canonical formalism has increased predictability, as illustrated by the split between majority and dissent in BFP v Resolution Trust Corp., 511 U.S. 531 (1994), involving whether a canon was sufficiently "established" to justify departure from the ordinary meaning of text).

88. See Brudney \& Ditslear, supra note 38, at 103-05.

89. See, e.g., Gen. Dynamics Land Sys. Inc. v. Cline, 540 U.S. 581, 594-97, 603-04 (2004) (Souter \& Thomas, JJ., disagree about application of whole act rule); Chickasaw Nation v. United States, 534 U.S. 84, 89, 97-98 (2001) (Breyer \& O'Connor, JJ., disagree about whether to ignore or apply canon against surplusage); Mackey v. Lanier Collection Agency, 486 U.S. 825, 836-37, $842-43$ (1988) (White \& Kennedy, JJ., disagree about which interpretation truly furthers whole act rule); Lehman v. Nakshian, 453 U.S. 156, 163-64, 173-74, 177-78 (1981) (Stewart \& Brennan, JJ., disagree about which interpretation is consistent with in pari materia canon).

90. See, e.g., Christensen v. Harris County, 529 U.S. 576, 583-84, 593-94 (2000) (majority and dissent debate applicability of expressio unius to a provision of Fair Labor Standards Act); John Hancock Life Ins. v. Harris Trust \& Sav. Bank, 510 U.S. 86, 96-97, $112-12$ (1993) (majority and dissent disagree on applicability of expressio unius to text of ERISA); Breininger v. Sheet Metal Workers, 493 U.S. 67, 91-92, 97-98 (1989) (majority and dissent disagree on applicability of ejusdem generis).

91. CASEBOOK, supra note 2, at 947.

92. See, e.g., West v. Gibson, 527 U.S. 212, 217-22, 225 (1999) (rejecting language canon argument and relying on legislative history, purpose, and inaction); Varity v. Howe, 516 U.S. 489 , 511 (1996) (using language canon to raise a question about congressional intent); Bufferd v. Comm'r, 506 U.S. 523, 529-30 (1993) (deflecting language canon argument as unpersuasive and relying instead on legislative history and agency interpretation to support its view of text). 
case-by-case reputation for rational or principled decision making, but they do not materially enhance drafting efficiency, and their value in this regard should not be overstated.

\section{Signaling the Intensity of the Court's Policy Preferences}

Also in the Supreme Court Foreword, Frickey maintains that the substantive canons should be viewed as potent signaling devices. ${ }^{93}$ Under this theory, the Court has applied numerous strong presumptions and clear statement rules to confine statutory meaning because the Court is uncomfortable with certain policy judgments reached by Congress, ${ }^{94}$ or relatedly because the Court seeks to protect what it views as underenforced constitutional norms. ${ }^{95}$ Frickey presents three areas in which the Court's effort to vindicate preferred values or norms is well developed: the Rehnquist Court's use of the rule of lenity, the longstanding canons resolving ambiguities in favor of Indians, and the Warren Court's reliance on the constitutional avoidance canon.

First, the conservative law-and-order Rehnquist Court invoked the rule of lenity in a series of decisions to help justify its reversal of criminal convictions. ${ }^{96}$ The Justices acted in this way partly to vindicate traditional due process values reflected in the concept of lenity. ${ }^{97}$ More important in Frickey's view, however, is that Congress's persistent efforts to nationalize crime conflicted with the Court's strong commitment to respect the values of federalism and to minimize new burdens on the lower courts' docket. ${ }^{98}$

Second, in the field of federal Indian law, the Court has longstanding canons requiring that ambiguities in treaties and statutes be resolved in favor of the Indians. ${ }^{99}$ An expert in Indian law, Frickey has written extensively about the Court's uses of these canons to protect the interests, property rights, and sovereignty of Indian tribes unless Congress has clearly expressed a contrary intent. ${ }^{100}$ The canons are "rooted in the unique trust relationship" that has long

93. See Eskridge \& Frickey, supra note 16 , at $68-70$.

94. See id. at 69-70.

95. See Frickey, Interpretation on the Borderline, supra note 52, at 128.

96. See id. (discussing Ratzlaf v. United States, 510 U.S. 135 (1994) and Staples v. United States, 511 U.S. 600 (1994)). For additional examples, see Cleveland v. United States, 531 U.S. 12 (2000); Jones v. United States, 529 U.S. 848 (2000); Bailey v. United States, 516 U.S. 137 (1995); McNally v. United States, 483 U.S. 350 (1987).

97. See Eskridge \& Frickey, supra note 16, at 70 (discussing Court's concerns about strict liability for crimes that are not malum in se).

98. See id. at 70-71.

99. See, e.g., Minnesota v. Mille Lac Band of Chippewa Indians, 526 U.S. 172, 200 (1999); N. Cheyenne Tribe v. Hollowbreast, 425 U.S. 649, 655 n.7 (1976); Choctaw Nation v. United States, 318 U.S. 423, 431-32 (1943); Choate v. Trapp, 224 U.S. 665, 675 (1912).

100. See, e.g., Felix S. Cohen, Cohen's HandBook of Federal Indian Law 119-22 (3d ed. 2005) (Frickey authored the handbook's discussion of the canons, see Email from Ethan $\mathrm{H}$. Shaw, LexisNexis, to Melanie Oberlin, Moritz College of Law (May 26, 2009) (on file with author)); Philip P. Frickey, Marshalling Past and Present: Colonialism, Constitutionalism, and Interpretation in Federal Indian Law, 107 HARv. L. REV. 381, 440 \& n.249 (1993) [hereinafter 
existed between the United States and the Indians. ${ }^{101}$ Frickey views the trust relationship as based primarily on structures of sovereignty within our system of government rather than on judicial solicitude for Indians as powerless minorities. ${ }^{102}$ Like the federalism values underlying the Court's recent rule-oflenity jurisprudence, the Indian law canons have a quasi-constitutional statusthey furnish an interpretive framework that presumptively privileges sovereign interests distinct from those asserted by Congress through federal statutes. ${ }^{103}$

Finally, Frickey has examined the Warren Court's use of the constitutional avoidance canon to address the rights of individual dissenters in a national security setting. ${ }^{104}$ In a series of cases decided during the 1950 s, the Court narrowed the scope of laws and other directives that sought to remove "disloyal" or "subversive" individuals from federal employment ${ }^{105}$ or to punish them for refusing to answer questions posed by the federal government. ${ }^{106}$ The Court's interpretations repeatedly ignored Congress's evident disciplinary intent. In Frickey's view, the explanation for these decisions was the Justices' interest in protecting the underenforced constitutional norms of free expression and privacy during a period when explicit constitutional lawmaking to protect those norms would likely have failed and have provoked strong public hostility. ${ }^{107}$ The Warren Court applied this canonical approach even when the statute under review was not ambiguous-all the Justices in the majority required was that Congress had not actively considered or explicitly taken responsibility for the serious consequences to individual rights that could follow from the text it approved. ${ }^{108}$ Frickey's analysis suggests that the Warren Court of the 1950s and the Rehnquist Court of the 1990s may have shared a

Frickey, Marshalling Past and Present].

101. County of Oneida v. Oneida Indian Nation, 470 U.S. 226, 247 (1985).

102. See CoHEN, supra note 100, at 122-23; Philip P. Frickey, (Native) American Exceptionalism in Federal Public Law, 119 HARv. L. REv. 431, 439-40, 477-81 (2005) [hereinafter Frickey, (Native) American Exceptionalism]; Frickey, Marshalling Past and Present, supra note 100 , at $425-26$.

103. See CoHEN, supra note 100, at 126-127; Philip P. Frickey, A Common Law for Our Age of Colonialism: The Judicial Divestiture of Indian Tribal Authority over Nonmembers, 109 YALE L.J. 1, 76 (1999). The presumptive privileging of Indian sovereign interests has been curtailed by Court decisions in recent decades, as Frickey has trenchantly observed. See id. at 5873; Frickey, (Native) American Exceptionalism, supra note 102, at 452-72.

104. See Frickey, Getting from Joe to Gene, supra note 5.

105. See, e.g., Peters v. Hobby, 349 U.S. 331, 337-48 (1955) (narrowly construing Civil Service Commission Loyalty Review Board's jurisdiction in case of alleged disloyalty by petitioner); Cole v. Young, 351 U.S. 536 (1956) (narrowly construing federal statute); Communist Party v. Subversive Activities Control Bd., 351 U.S. 115, 122-25 (1956) (narrowly construing operation of federal statute in case of alleged subversive design by petitioner).

106. See, e.g., United States v. Rumely, 345 U.S. 41 (1953) (narrowly construing House resolution); United States v. Witkovitch, 353 U.S. 194 (1957) (narrowly construing federal statute); Watkins v. United States, 354 U.S. 178 (1957) (narrowly construing House resolution); Yates v. United States, 345 U.S. 298 (1957) (narrowly construing federal statute).

107. See Frickey, Getting from Joe to Gene, supra note 5, at 450-58.

108. See id. at 459-61. 
willingness to elevate certain policy preferences in the face of clear, though not unequivocally explicit, evidence that Congress intended a contrary outcome.

One could seek to justify these three instances of substantive canonsignaling in terms of the Court's effort to protect the politically powerless, as Professor Elhauge does in his recent book on statutory interpretation. ${ }^{109}$ Frickey, however, is more inclined to view the Court's signaling forays as efforts to protect substantive values, not individuals or groups. At the same time, Frickey is uncomfortable at the prospect that the Court's policy judgments in some areas may disrespect the will of Congress, ${ }^{110}$ a concern that applies regardless of whether the Court believes it is vindicating powerless groups or underenforced norms.

Perhaps more important, Frickey recognizes that it is not easy to know just what are underenforced norms or powerless groups. ${ }^{111}$ The Rehnquist Court regarded federalism values as constitutionally underenforced, notwithstanding the Court's quite recent and high profile constitutional rejection of a judicially enforced federalism approach. ${ }^{112}$ Further, although the Court's canon-inspired protections for criminal defendants may be easily overridden because of that group's politically impotent status, ${ }^{113}$ state governments are more formidable in protecting and advancing their own policy priorities. ${ }^{114}$

In sum, Frickey understands and appreciates that the Court's use of substantive canons to promote its own preferred outcomes may be difficult to confine. That we would applaud some institutionally based canon preferences and condemn others is not per se troubling-we presumably would have the same range of reactions to policy preferences and understandings expressed by Congress or the executive. But, once we view the canons as an institutional resource effectively promoting the Court's policy preferences, certain firstorder questions arise, as explained in Part II.

109. See ElHAUGE, supra note 12 , at 168-81, 186-87.

110. See Eskridge \& Frickey, supra note 16, at 71 (expressing discomfort with Court's use of Lenity); Frickey, Getting from Joe to Gene, supra note 5, at 446 (acknowledging the Warren Court's "aggressive rewriting of statutes" through the avoidance canon).

111. See Eskridge \& Frickey, supra note 50, at 597, 611-12 (describing Court's dramatic shift from 1970 s to 1980 s regarding which constitutionally based canons warranted aggressive enforcement).

112. Garcia v. San Antonio Metro. Transit Auth., 469 U.S. 528 (1985); see Eskridge \& Frickey, supra note 50, at 637 (noting how Court has used federalism canon to circumvent Garcia).

113. See William N. Eskridge Jr., Overriding the Supreme Court Statutory Interpretation Decisions, 101 YALE L.J. 331, $344-45$ (1991); see also Lori Hausegger \& Lawrence Baum, Behind the Scenes: The Supreme Court and Congress in Statutory Interpretation, in GREAT Theatre: The American Congress IN THE I990s 224, 240-42 (Herbert F. Weisberg \& Samuel C. Patterson eds., 1998) (finding overrides more than twice as likely when United States was a party on losing side).

114. See Larry Kramer, Understanding Federalism, 47 VAND. L. REV. 1485, 1520-59 (1994); see also Eskridge, supra note 113, at 351-52 (observing that states are unusually successful at obtaining congressional overrides of Supreme Court decisions). 
II

\section{The Canons as Subordinate to Legislative History AND AgEnCY DIRECTIVES}

\section{A. Comparing Branch-Specific Interpretive Assets}

Although federal courts are ultimately responsible for addressing controversies about the meaning of statutory language, courts regularly rely on contextual resources from all three branches when resolving disputes. Since the 1980 s, judges and scholars have increasingly debated the comparative merits of branch-specific interpretive assets, especially the merits of canons and legislative history. ${ }^{115}$ Normative debates revolve primarily around issues of legitimacy and reliability. In terms of legitimacy, Justice Scalia and other textualists have contended that legislative history is suspect in constitutional terms ${ }^{116}$ and have implied that canons-as freestanding policy or language maxims steeped in custom or practice-have a law-like respectability that is missing from legislative record documents opportunistically created in a partisan and politicized environment. ${ }^{117}$ In terms of reliability, legal process scholars have trumpeted the canons' value as gap-filling principles that enhance the clarity and predictability of enacted text; ${ }^{118}$ again, this contrasts with politically-tinged, messy legislative history, deemed by textualists to be susceptible to judicial manipulation. ${ }^{19}$

Professor Frickey's contributions with respect to the canons have generated a rich collection of descriptive and normative insights. Many of these insights address the canons' role in promoting values and policies favored by the judicial branch. My intention is to broaden and deepen Frickey's institutional focus, by exploring how the canons measure up as an institutional resource when compared with legislative history and agency guidance-core interpretive resources generated by the two other branches. In moving beyond critical analysis of the canons as a self-contained interpretive asset, I suggest

115. Compare, e.g., SCAlia, supra note 6, at 25-37, with STEPHEN BREYER, ACTIVE LiBERTY: INTERPRETING OUR DEMOCRATIC CONSTITUTION 85-102 (2005) (disagreement among Supreme Court Justices); Shapiro, supra note 6, at 943-45, with RiCHARD A. POSNER, ThE FEDERAL COURTS: CRISIS AND REFORM 276-83 (1985) (disagreement about merits of the canons); Frank H. Easterbrook, What Does Legislative History Tell Us?, 66 CHI.-KENT L. REv. 441, 447 (1990), with Lawrence M. Solan, Private Language, Public Laws: The Central Role of Legislative Intent in Statutory Interpretation, 93 GEO. L.J. 427, 437-42 (2005) (disagreement about merits of legislative history).

116. See, e.g., SCALIA, supra note 6, at 31; Alex Kozinski, Should Reading Legislative History Be an Impeachable Offense?, 31 Suffolk U. L. Rev. 807, 813 (1998); Kenneth W. Starr, Observations About the Use of Legislative History, 1987 DUKE L.J. 371, 375-76 (1987).

117. See, e.g., Frank H. Easterbrook, Text, History, and Structure in Statutory Interpretation, 17 HARv. J. L. \& PuB. PoL'y 61, 61 (1994); John F. Manning, Legal Realism and the Canons' Revival, 5 GreEn BAG 2D 283, 284-85, 290-95 (2002).

118. See SunSTEIN, supra note 6, at 147-57; Eskridge \& Frickey, supra note 16, at 67.

119. See, e.g., Easterbrook, supra note 115, at 447; Kozinski, supra note 116, at 813. 
why, in systemic terms, the canons should be ranked distinctly below the political branch interpretive assets.

To be clear, I believe that the contextual resources of all three branches play situationally important roles in helping courts resolve particular disputes, and that they should continue to do so. Moreover, I have recently written about the need to avoid a one-size-fits-all approach when assessing the virtues and vices of legislative history or the canons. ${ }^{20}$ Nonetheless, I maintain that from the standpoint of legitimacy, canons should be regarded as institutionally suspect when compared with legislative history; and, from the standpoint of objective reliability, as inferior to both legislative history and agency guidance. These arguments support the need to shift interpretive emphasis away from textualist and canon-centered approaches, where it has often been since the late 1980s, and towards more purposive and pragmatic approaches that favor interpretive resources generated by Congress and the executive.

\section{B. Legitimacy}

Statutory interpretation is predicated on respect for the lawmaking supremacy of Congress and for text as the final product of a representative and deliberative democratic process. This democratic deliberation results in a considerable amount of vagueness in enacted language. Although Congress could perhaps do a better job of removing unnecessary vagueness, ${ }^{121}$ the persistence of inconclusive language is both inevitable and valuable. ${ }^{122}$ It is impossible to explore all policy implications accompanying different ways to draft a complex regulatory scheme. ${ }^{123}$ Further, to avoid procedural roadblocks and secure compromise, language must be drafted or modified so as to achieve support even at some cost in clarity. ${ }^{124}$

Where the Constitution suggests courts might look for interpretive assistance, the canons are not referenced at all. This is unsurprising given Article III's silence on techniques or methods of judicial review. ${ }^{125}$ At the same

120. See Brudney \& Ditslear, supra note 55 (discussing how Court's use of legislative history and canons varies from one subject matter area to another); James J. Brudney, The Supreme Court as Interstitial Actor: Justice Ginsburg's Eclectic Approach to Statutory Interpretation, 70 Oнго ST. L.J. 889 (2009) (contending that one Justice's varying reliance on canons and legislative history is shaped by pragmatic interest in fostering institutional dialogue).

121. See, e.g., Nicholas Quinn Rosenkranz, Federal Rules of Statutory Interpretation, 115 HaRv. L. Rev. 2085, 2143-57 (proposing that Congress codify rules of statutory interpretation).

122. See Joseph A. Grundfest \& A. C. Pritchard, Statutes with Multiple Personality Disorders: The Value of Ambiguity in Statutory Design and Interpretation, 54 STAN. L. REv. 627, 630, 640-42 (2002); see also James J. Brudney, Congressional Commentary on Judicial Interpretation of Statutes: Idle Chatter or Telling Response?, 93 MICH. L. Rev. 1, 21-40 (1994).

123. See Henry S. Richardson, Democratic Autonomy 116-18 (2002).

124. See Nourse \& Schacter, supra note 67, at 594-97, 615-16; see also Brudney, supra note 122 , at $29-32$.

125. Article 3, Section 1 authorizes a system of federal courts and sets a compensation standard for federal judges; Section 2 specifies federal jurisdiction; Section 3 addresses treason. 
time, the Constitution plants the seeds for what we now think of as legislative history by empowering Congress to "determine the Rules of its Proceedings," 126 and by requiring each House to "keep a Journal of its Proceedings, and from time to time publish the same."127 The Journal Clause's origins and historical context indicate the Framers believed it was important to have a publicly accessible record of how and why Congress reached the decisions it did, and that such a record was essential to promote broader understanding of legislative action.

\section{The Record of Floor Debates}

Discussions of the Journal Clause at the Convention and during Ratification by the states indicate broad support for publication-not simply because of how members voted but also because of positions taken during the proceedings. ${ }^{128}$ The text of Article I, Section 5 confirms this: it requires each House to record voting by members and to keep a record of overall proceedings. $^{129}$

The Constitution's insistence on publication and against secrecy was a relatively new legislative design feature in the Anglo-American setting. The British Parliament had long operated in secrecy, punishing those persons who sought to publish records of its proceedings. ${ }^{130}$ The Continental Congress

The only mention of how courts are to function is the requirement for a jury trial in federal criminal cases. U.S. ConST. art. III, $\$ 2$, cl. 3.

126. Id. art. I, $\S 5$, cl. 2.

127. Id. cl. 3 .

128. See, e.g., 2 The Founders' Constitution 290-91 (Philip B. Kurland \& Ralph Lerner eds., 1987) (remarks of James Wilson at Federal, Sept. Convention 14, 1787); id. at 29293 (remarks of George Mason at Virginia Ratifying Convention, June 14-15, 1788); id. at 294 (debate in North Carolina Ratifying Convention, July 26, 1788). The debates reveal a strong commitment to publishing the journals of Senate and House proceedings-debates focused on how the Constitution should clarify exceptions for highly sensitive military and diplomatic transactions. See Daniel N. Hoffman, Governmental Secrecy and the Founding Fathers 26-28, 35-37 (1981). See generally JOSEPH STORY, 2 COMMENTARIES ON THE CONSTITUTION $\S 838$ (1833) ("The object of the whole clause [I.5.3] is to ensure publicity of the proceedings to the legislature, and a correspondent responsibility of the members to their respective constituents.").

129. See U.S. CONST. art. I, § 5, cl. 3; see also STORY, supra note 128 , at $\S 839$.

So long as known and open responsibility is valuable as a check, or an incentive among the representatives of a free people, so long a journal of their proceedings, and their votes, published in the face of the world, will continue to enjoy public favour, and be demanded by public opinion.

Id. (emphasis added).

130. See G. H. Jennings, An Anecdotal History of the British Parliament from THE EARLIEST Periods 559 (Horace Cox 4th ed. 1899). By the mid-eighteenth century, early reporting on parliamentary debates included some outright fabrication of members' speeches by persons who had not been present at the debates. See id. at 561; see also Parliament Home Page Hansard (official report), http://www.parliament.uk/about/livingheritage/evolutionofparliament/ communicating/keydates/publicationofofficialreport.cfm (last visited Mar. 19, 2010) [hereinafter History of Hansard] (stating that suppression of unofficial printings of debates did not cease until 
swore its members to secrecy and initially refused to publish any of its proceedings, ${ }^{131}$ while the Constitutional Convention excluded outsiders during its entire deliberative process. ${ }^{132}$ To be sure, contrary design approaches were emerging - the British Parliament allowed for reporting of proceedings in the reign of George III, ${ }^{133}$ and the Articles of Confederation and some early state legislatures provided for journals of their proceedings. ${ }^{134}$ Still, the requirement of published legislative proceedings was an innovation, based on a belief that transparency in the deliberative process would promote responsibility of members to their constituents and that "[ $t]$ he public mind [would be] enlightened by an attentive examination of . . public measures."135

Although the House and Senate Journals are summaries of the floor proceedings that do not record debates and discussions, ${ }^{136}$ members of Congress understood from the beginning that the commitment to publication encompassed reporting on the debates as well. ${ }^{137}$ In April 1792, Rep. Elbridge Gerry offered the first proposal for the House to appoint official stenographers who would transcribe and publish the debates. ${ }^{138}$ Importantly, Gerry contended

1771). See generally Adrian Vermeule, The Constitutional Law of Congressional Procedure, 71 U. CHI. L. REv. 361, 411 (2004).

131. See Hofman, supra note 128 , at 14; Edmund Cody Burnett, The Continental CONGRESS 67 (Norton 1964) (1941); Vermeule, supra note 130; see also Senate Historical Office, Reporters of Debate and the Congressional Record, http:/www.senate.gov/artandhistory/history/ common/briefing/Reporters_Debate_Congressional_Record.htm (last visited Mar. 19, 2010) (describing Continental Congress having closed its doors to the public and the press).

132. See 1 The Records of the Federal Convention of 1787 xi-xxv (Max Farrand ed., rev. ed. 1966); BuRNETT, supra note 131, at 691-92.

133. See HofFMAN, supra note 128, at 13; History of Hansard, supra note 130 (suppression of printed debates ends in 1771); House of Commons Info. OfFice, Factsheet G3 General Series: A Brief Chronology of the House of Commons 8 (Apr. 2009) available at http:/www.parliament.uk/documents/upload/G03.pdf (newspaper reporters are first allocated seats in public gallery in 1803).

134. See Hoffman, supra note 128, at 13-14; 2 The Founders' Constitution, supra note 128, at 289 (quoting Articles of Confederation, calling for monthly publication of journals with exception for parts requiring secrecy because "relating to treaties, alliances or military operations"); id. at 301 (quoting James Wilson's Lectures on Law in 1791, referring to Constitution of Pennsylvania that required journals to be published weekly).

135. STORY, supra note $128, \S 838$, quoted in Field v. Clark, 143 U.S. 649, 671 (1892).

136. See Robert C. Byrd, 2 The Senate 311-12 (1991); Mildred Amer, Congressional Research Service, The Congressional Record; Content, History and IsSUES 1 (Jan. 14, 1993).

137. See Elizabeth Gregory McPherson, Reporting the Debates of Congress, Q. J. SPEECH, Apr. 1942, 141, reprinted in 88 CoNG. REC. A2182 (1942) (extension of remarks of Rep. Mundt, June 10, 1942); see also AMER, supra note 136, at 2-3.

138. See McPherson, supra note 137, at 142-43; Samuel OpPenheim, The Early Congressional Debates AND Reporters 10-11 (1889) (Paper read at Fourteenth Annual Meeting of N.Y. State Stenographers Assn). Rep. Gerry had been a delegate to the Continental Congress and the Constitutional Convention, and one of the signers of the Declaration of Independence and the Articles of Confederation. Subsequently, he served as Governor of Massachusetts and as Vice President under President Madison. See George Athan Billias, Elbridge Gerry: Founding Father and Republican Statesman 68-81, 89, 153-206, 30829 (1976) 
that in addition to informing citizens about the reasons or motives underlying the conduct of their representatives, impartial publication of floor debates was desirable to "aid the Executive in administering the Government [and] the Judiciary in expounding the laws.",139

Congressional debates were initially published not through official reporters but by commercial journalists, who were admitted to the chamber (along with the public at large) to sit in galleries or on the legislative floor. Their reports were later distributed through newspaper publication by use of the franking privilege. ${ }^{140}$ The House began admitting journalists starting in 1789 , and by 1795 both chambers allowed for published proceedings-albeit fitfully due to economic considerations and periodic pique with the accuracy or honesty of particular journalists. ${ }^{141}$

\section{The Record of Standing Committees}

Alongside the Journal Clause, the Constitution authorizes each chamber of Congress to create rules that will determine the structure of its internal proceedings. ${ }^{142}$ Initially, both the House and Senate appointed scores of select committees to serve during each session of Congress, directing them to draft particular texts or to address specific policy problems. ${ }^{143}$ Under this improvised approach, select committees were responsive to the chamber as a whole, which used them essentially as technical aids. ${ }^{144}$

139. OPPENHEIM, supra note 138 , at 10 . The Gerry Resolution was referred to a committee but no action was taken on the committee report. Id. at 12 .

140. See HoFman, supra note 128, at 49-50; McPherson, supra note 137, at 142-43; see

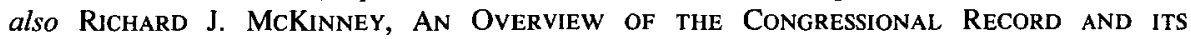
Predecessor Publications 1 (Apr. 2005) available at http://www.llsdc.org/attachments/ wysiwyg/544/cong-record.pdf (last visited Apr. 18, 2010) ("There was no precedent in colonial or English legislative practice for more then [sic] just the keeping of official journals, but from early on unofficial commercial reporters were allowed access to the House and Senate chambers."). The franking privilege, created by Congress, allows certain materials to be sent through the U.S. mail without postage. See Matthew Eric Glassman, Congressional Research Service, Franking Privilege: Historical Development and Options for Change (Dec. 5, 2007) (describing how Congress from 1789 onward has authorized its members and officials to transmit postage-free mail conveying information about congressional business).

141. See McPherson, supra note 137, at 142-43; AMER, supra note 136, at 2-3; see also Byrd, supra note 136, at 312; DonAld A. RITCHIE, Press Gallery 7-8 (1991) (discussing initial decision by House members to open congressional proceedings to the press, as members confronted both "their desire for newspaper coverage and their inability to control the substance of the reporting").

142. U.S. CONST. art. I, $\S 5$, cl. 2. See 2 STORY, supra note 128, $\S 835$ ("No person can doubt the propriety of the provision authorizing each house to determine the rules of its own proceedings. If the power did not exist, it would be utterly impracticable to transact the business of the nation, either at all, or at least with decency, deliberation, and order.").

143. See Walter Kravitz, Evolution of the Senate's Committee System, in CHANGING Congress: The CommitTeE System 27, 28 (Norman J. Ornstein ed., 1974) [hereinafter Changing Congress]; David T. Canon et al., 1 Committees in the U.S. Congress, i 789 I946 xxxviii (2002).

144. See Steven S. Smith \& Christopher J. Deering, Committees in Congress 10-12 
Between 1789 and 1820, however, the House and Senate shifted from relying on temporary select committees to relying on permanent standing committees that were created to shape the priorities and agenda of each chamber. ${ }^{145}$ The change has been attributed to multiple factors, including the inconvenience of constantly creating new ad hoc bodies, the uneven workload distribution among members, the failure to take sufficient advantage of subject matter expertise possessed by individual legislators, and the need for a more effective Congress to address the problems of an expanding nation and to counteract the growing influence of the President. ${ }^{146}$ This permanent standing committee approach - in which bills are reviewed and reported before full chamber consideration-was also a novel legislative design feature. It differs dramatically from the British Parliament's committee structure, which to this day relies on standing committees that lack permanent subject-matter jurisdiction, that are without continuing membership, and that consider a bill in detail only after a vote approving the measure in principle by the full House. ${ }^{147}$

During the first half of the nineteenth century, Congress continued to address the importance of reporting on floor debates and relying on standing committees. ${ }^{148}$ By the 1840 s, a series of commercial printers employed by

(1984); see also CANON ET AL., supra note 143, at xxxviii; Kravitz supra note 143, at 29; United States Senate - Senate Committees, http:/www.senate.gov/artandhistory/history/common/ briefing/Committees.htm (last visited Apr. 6, 2010) [hereinafter Senate Committees].

145. See CANON ET. AL., supra note 143, at $\mathrm{xxxix}-\mathrm{xl}$; William L. MorRow, Congressional Commitrees 14-15 (1969); Nelson W. Polsby, The Institutionalization of the U.S. House of Representatives, 62 AM. PoL. SCI. REv. 144, 153-56 (1968); Senate Committees, supra note 144.

146. See CANON ET. AL., supra note 143, at xxxix-xl; Morrow, supra note 144 at 14-15; Polsby, supra note 145, at 154-55; Kravitz, supra note 143, at 29-30; Senate Committees, supra note 144.

147. See James J. Brudney, Below the Surface: Comparing Legislative History Usage by the House of Lords and the Supreme Court, 85 WASH. U. L.R. 1, 40-42 (2007); see also Garrison Nelson, Assessing the Congressional Committee System: Contributions from a Comparative Perspective, in Changing Congress, supra note 143, at 120, 123-24. See generally RalPH Volney Harlow, The History of Legislative Methods in the Period Before i825 3-5 (1917) (discussing how standing committees were used to a limited extent in Parliament in late sixteenth century but had ceased to be a factor in legislative work well before American independence). The colonial and early state legislatures relied on a mix of tightly controlled select committees and preliminary versions of standing committees; the latter may well have influenced the creation of permanent standing committees in Congress. See Lauros G. McConachiE, Congressional Committees 17-25 (1898); Peverill Squire \& Keith E. Hamm, 101 Chambers: Congress, State Legislatures, and the Future of Legislative Studies 106 (2005).

148. See OPPENHEIM, supra note 138, at 32-50 (discussing recurrent floor debates in House from 1800 to 1827 , in which proposed and enacted Rules emphasized the need for accurate reporting of floor debates); RITCHIE, supra note 141, at 12-30 (describing rise of officially designated printers of House and Senate debates, along with small cohort of regular reporters on floor proceedings); see also McConACHIE, supra note 147, at 97, 124-38 (describing expansive and growing influence of standing committees from 1815 to 1850); Thomas F. Broden, Jr., Congressional Committee Reports: Their Role and History, 33 Notre DaME LAw. 209, 226-30 (1968) (describing development of detailed and informative committee reports between 1820 s and 
Congress had moved toward verbatim and nonpartisan accounts of floor discussion, with a congressional requirement that legislators receive copies of these published reports. ${ }^{149}$ After 1873, when the Government Printing Office began publishing the Congressional Record, there was a complete and comprehensive method for recording congressional proceedings and debates. ${ }^{150}$

Publication of and member reliance on standing committee reports also dates from the early and mid 1800 s. By 1830 , detailed House committee reports were often invoked during floor debates. ${ }^{151}$ Although many reports accompanying committee bills were delivered orally by committee chairs or floor managers, written reports became prevalent in the House between 1830 and $1860 .^{152}$ The Senate followed slightly behind the House in creating and relying on written standing committee reports, but by 1900 committee reports accompanied bills recommended for full consideration in both chambers as a matter of rule or custom. ${ }^{153}$

\section{The Constitutional Foundation of Legislative History as an Interpretive Resource}

Legislative record documents, developed pursuant to the provisions of Article I, were originally created primarily to keep the public informed. ${ }^{154} \mathrm{But}$ from an early point, representatives and senators also understood the importance of these documents for keeping themselves informed, enabling members to vote more intelligently and responsibly on policy measures considered by the full body. ${ }^{155}$ It therefore is not surprising that by the time of

Civil War).

149. See OPPENHeIM, supra note 138, at 51; see also BYRD, supra note 136, at 314; RitcHIE, supra note 141, at 29-30; McPherson, supra note 137, at 146-47; AMER, supra note 136, at $4-5$.

150. See AMER, supra note 136, at 5-6; Senate Historical Office, supra note 131, at 2.

151. See MCCONACHIE, supra note 147, at 60, 400-01; Broden, supra note 148, at 228 .

152. See Broden, supra note 148 , at 229.

153. See WM. Holmes Brown \& Charles Johnson, House Practice 281 (2003) (dating House requirement from 1880); Broden, supra note 148, at 238 (dating Senate majority practice from 1900). See generally Woodrow WiLSON, Congressional GovernMENT 90-91 (Meridan Books 1973) (1885) (contrasting British system, which relies on majority party cabinet as a "single standing committee that is charged with the origination of legislation," with American system, which relies on "a [series of] Standing Committee[s], drawn from both parties, for the consideration of each topic of legislation").

154. See supra notes $135-138$ and accompanying text.

155. See, e.g., MCCONACHIE, supra note 147, at 60 (reporting a House member's statement in 1829 that printed committee reports were for the enlightenment of the House as well as public opinion); WILSON, supra note 153, at 71 (observing that "[a] Committee is commissioned, not to instruct the public, but to instruct and guide the House"); JAMES Bryce, THE AMERICAN COMMONWEALTH 148, 155-57 (1891) (discussing how members rely heavily on reports from standing committees to guide and shape their positions); see also OPPENHEIM, supra note 138, at 32-33 (reporting House member's statement in 1800, emphasizing that the reasons behind legislators' conduct "should be clearly understood in order that their measures might be comprehended and their motives known," quite apart from enabling their constituents to "judge 
the Civil War and Reconstruction, Congress had ordered daily publication and delivery of full chamber proceedings to all members, ${ }^{156}$ and distribution of committee reports to members had become prevalent. ${ }^{157}$

This evolution in the role of legislative record documents is relevant to the judicial branch role as well. The processes of our representative democracy regularly involve bill introduction followed by discussion and crafting of compromise language to overcome procedural obstacles and secure legislator approval. ${ }^{158}$ Legislative deals or bargains are a well-recognized feature of American lawmaking, and legislative history often helps illuminate the existence of a compromise or explain subtle aspects of the bargain. ${ }^{159}$ That explanation is valuable for members as they decide how to vote, and also for executive branch agencies and sophisticated members of the public-watchdog groups, regulated entities, and their attorneys-as they decide how to conform their own conduct. ${ }^{160}$ Accordingly, just as the Founders wanted the public to have a record so they could understand what "their Agents are doing or have done," standing committees to shape their legislative agendas and have sought access to information produced by these standing committees. Members' appreciation for the role of the legislative record in helping them to understand the nature of

whether they had faithfully discharged their duty"); supra text accompanying note 139 (reporting Rep. Gerry's statement in 1792 that documentation of floor debates would help executive branch to administer the laws and would aid the courts in interpreting these laws).

156. See supra notes $149-150$ and accompanying text.

157. See supra notes 151-153 and accompanying text.

158. See Richardson, supra note 123, at 204; see also Alan Grant, The AmERican Political Process 45-52, 65-66, 302 (5th ed. 1994); Brudney, supra note 147, at 45-46.

159. See, e.g., Doe v. Chao, 540 U.S. 614, 622-23 (2004); Landgraf v. USI Film Prods., 511 U.S. 244, 250-63, 280, 286 (1994); James J. Brudney \& Corey Ditslear, Liberal Justices' Reliance on Legislative History: Principle, Strategy, and the Scalia Effect, 29 BERKELEY J. EMP. \& LAB. L. 117, 146-53 (2008).

160. See Broden, supra note 148, at 209-10, 214; James J. Brudney, Intentionalism's Revival, 44 SAN DiEgo L. REv. 1001, 1011-12 (2007) (discussing ex ante value of committee reports for members and ex post value for lobbyists, press, and public). The Constitution also references the President's need for guidance from executive department officers. U.S. CONST. art. II, $\S 2, \mathrm{cl} .1$. This in turn relates to the President's obligation to "take Care that the Laws be faithfully executed." Id. $\S 3$. Although the requirement of faithful execution principally reflected a concern to prohibit the President from suspending laws that had been enacted, some participants understood the provision also to require executive interpretation of inconclusive text. See 4 THE Founders' Constitution, supra note 128, at 123, 126 (quoting a Letter from William Symmes to Captain Peter Osgood, Nov. 15, 1787, during Massachusetts Ratifying Convention: "Can we exactly say ... . what may be called or comprehended in a faithful execution? . . . Should a Federal law happen to be as generally expressed as the President's authority; must he not interpret the Act! For in many cases he must execute the laws independent of any judicial decision."). See generally Mashaw \& Perry, supra note 12 (analyzing early examples of agency statutory interpretation); Mashaw, supra note 12 (analyzing early examples of agency statutory interpretation).

161. James Wilson, Statement at the Federal Convention (Sept. 14, 1787), reprinted in THE FOUNDERS' Constitution, supra note 128, at 291. 
legislative bargains, and the meaning of text on which they will vote, remains robust to this day. ${ }^{162}$ The federal courts — charged with resolving disputes about the meaning of often-complex regulatory compromises-have a historically grounded responsibility to examine the same record for parallel reasons. ${ }^{163}$

It does not follow from this constitutional foundation that courts should rely on legislative history in all or even most settings. There remain numerous instances in which the legislative record is vague, silent, or suspect, and also instances where other resources (Supreme Court precedent, agency guidance, even canons) have superior probative value. Still, the existence of its constitutionally and functionally linked origins confers upon legislative history an element of authoritative legitimacy that enhances its stature as an interpretive asset. This legitimacy is something legislative history skeptics have largely ignored.

\section{The Canons and Lawmaking Realities}

The canons lack the constitutional imprimatur possessed by legislative history. Their contributions, and indeed their existence, were not anticipated as part of the federal lawmaking structure. ${ }^{164}$ The pragmatic perspectives of modern legislators and their staffs reinforce this constitutional silence. It is understood that today's members of Congress are basically unaware of the canons' existence, much less their role in judicial construction of statutes. ${ }^{165}$ Perhaps as important, available empirical evidence indicates that canons are at best a peripheral drafting asset, rarely invoked by committee staff or legislative counsel when composing and negotiating over text. ${ }^{166}$

162. See Brudney \& Ditslear, supra note 55, at 1292 \& n.249 (referencing multiple statements from Republican and Democratic legislators since late 1980s).

163. Professor Vermeule has suggested that the Journal Clause's goal of promoting transparency in the lawmaking process may be frustrated because most of the real legislative bargaining occurs in less accessible venues such as off the floor or in closed markup sessions. See Vermeule, supra note 130 , at 413 . In practice, however, much of the bargaining must be sufficiently public to attract other members who are undecided. Further, even bargaining that is secret must be recognized or recorded in order for the terms of the bargain to be clear enough so that others can be persuaded to sign on. Staged floor colloquies and conference report statements of the bill managers are often examples of this kind of record.

164. See supra note 125 and accompanying text.

165. See Posner, supra note 80, at 806; see also Robert A. Katzmann, Bridging the Statutory Gulf Between Courts and Congress: A Challenge of Positive Political Theory, 80 Geo. L.J. 653, 662-65 (1992); Eric Lane, Legislative Process and Its Judicial Renderings: A Study in Contrasts, 48 U. Pirr. L. Rev. 639, 651, 656 (1987); Abner J. Mikva, Reading and Writing Statutes, 48 U. PITT. L. REv. 627, 629-31 (1987). This is not altogether surprising, given that roughly half the members are not lawyers and those who are have likely been away from legal practice for many years. See Jeffrey W. Stempel, Lawyers, Democracy and Dispute Resolution: The Declining Influence of Lawyer-Statesman Politicians and Lawyerly Values, 5 NEV. L.J. 479, 484 (2005); James Salzer, Lack of Lawyer-Legislators May Help Tort Reform Pass, ATLANTA J. Const., Mar. 27, 2003, at D1.

166. Nourse \& Schacter, supra note 67, at 597-605 (describing views of committee staffers and legislative counsel); Breyer, supra note 67, at 870-71 (questioning whether legislators are 
The lawmaking enterprise's lack of reliance on the canons makes sense from an institutional perspective. Legislators and staff draft statutes as part of an effort to generate consensus from the divergences and disagreements that are constitutive of American politics. Their goal is creating agreement sufficient to secure enactment, not with a primary focus on grammatical or lexigraphic clarity. ${ }^{167}$ That canons are of minimal relevance in the drafting process, and lack the constitutional grounding of legislative history, does not mean they lack institutional value as objective mechanisms for resolving disputes about the application of statutory text-if indeed they are objective. But it turns out that canons are inferior to both legislative history and agency guidance from the standpoint of objectivity as well.

\section{Objective Reliability}

Statutes are a form of communication. They are a privileged form because the Constitution authorizes Congress alone to prescribe legislative rules of general applicability that help structure and guide public behavior. ${ }^{168}$ As a form of communication, statutes are not self-explanatory: interpretation is needed to translate enacted language and give it meaning in real-life settings. ${ }^{169}$ Because the consequences of statutory interpretation are so substantial in shaping human conduct, we expect this interpretation to be reliable - to be based on "rule"-like or "standard"-like directives that are more objective than subjective. 170

There is considerable debate over the comparative virtues of rules and standards as interpretive approaches. Rules are often justified as offering greater certainty while standards are praised as being responsive to changes in the legal landscape. ${ }^{171}$ Despite these differences, proponents of both rules and

aided by knowledge that court-produced canons may govern future legislation, given a less-thanefficient legislative process characterized by partisan and decentralized bargaining); see also Robert A. Katzmann \& Stephanie M. Herseth, An Experiment in Statutory Communication Between Courts and Congress: A Progress Report, 85 GEO. L.J. 2189, 2192-93 (1997) (reporting that congressional committees are largely unaware of appellate court decisions construing statutory text); Robert A. Katzmann \& Russell R. Wheeler, A Mechanism for "Statutory Housekeeping": Appellate Courts Working with Congress, 9 J. APP. PRaC. \& Process 131, 140 (2007) (discussing project to make Legislative Counsel in House and Senate more aware of basic rules and conventions when drafting legislation). 657.

167. See Nourse \& Schacter, supra note 67, at 594-600,614-16; Lane, supra note 165, at

168. See, e.g., Boudreau et al., supra note 67, at 961-71; Solan, supra note 115, at 444-49.

169. See Frickey, Faithful Interpretation, supra note 5, at 1089.

170. For an overview on the difference between rules and standards as legal directives, see Kathleen M. Sullivan, Foreword: The Justices of Rules and Standards, 106 Harv. L. Rev. 22, 57-62 (1992). For discussion of how the distinction between rules and standards may be best understood as a continuum rather than a dichotomy, see, for example, Jules L. Coleman, Rules and Social Facts, 14 HaRv. J.L. \& PUB. PoL'y 703, 711-15 (1991); Michael S. Moore, Three Concepts of Rules, 14 HaRv. J.L. \& Pub. PoL'y 771, 794 (1991).

171. See generally Sullivan, supra note 170 , at 62 (discussing utility of rules); id. at 66 (discussing utility of standards); see also Carol M. Rose, Crystals and Mud in Property Law, 50 STAN. L. REV. 577, 590-92 (1988) (discussing arguments favoring rule-like directives); id. at 
standards embrace a core element of objectivity as part of their approaches. An objective framework is valued in part because it offers a measure of transparency, allowing us to observe and criticize the basis of interpretive judgments reached by courts or agencies. Relatedly, an objective structure imposes a measure of constraint on the discretion exercised by these interpreters. ${ }^{172}$ The law passed by Congress is not simply whatever courts or agencies say it means or want it to mean: rather, it is the best approximation of what Congress itself meant it to mean. ${ }^{173}$

Applying this preference for a core of objectivity to the interpretive assets of our three branches, the canons come out in third place. The Supreme Court's interpretive rubric has given rise to a fairly well-settled hierarchy of resources with respect to legislative history and a comparable framework for assessing different forms of agency guidance. These hierarchies, recognized by legal scholars and utilized by federal judges, have no parallel when it comes to the canons.

\section{Legislative History}

The hierarchy of reliable legislative history sources is tied to the structure of congressional lawmaking. Standing committee and conference committee reports are ranked at the top based on the central role of committees in formulating, justifying, and negotiating about text. ${ }^{174}$ They are regarded as capturing well-informed thought about what the proposed legislation is meant to accomplish, in a format that is both accessible and readily understandable. ${ }^{175}$ Explanatory floor statements by bill sponsors or managers are deemed almost as reliable, ${ }^{176}$ while legislative inaction, statements by non-legislative drafters-especially those on the losing side-and post-enactment history are arrayed toward the other end of the authoritative hierarchy. ${ }^{177}$ These rankings

592-93 (discussing arguments favoring standards-like directives).

172. See Antonin Scalia, The Rule of Law as a Law of Rules, 56 U. CHI. L. Rev. 1175 , 1179-80 (1989).

173. See Breyer, supra note 115 , at 85-88; William N. Eskridge, Jr., Philip P. Frickey, \& Elizabeth GarRetT, Legislation and Statutory INTERPRETATION 219-20, 231 (2d ed. 2006).

174. See Eskridge ET. AL., supra note 173, at 311-12; GreEnAwALT, supra note 46, at 173; William N. Eskridge Jr., The New Textualism, 37 UCLA L. Rev. 621, 636-37 (1990); see also Bank One Chicago, N.A. v. Midwest Bank \& Trust Co., 516 U.S. 264, 276-77 (1996) (Stevens, J., concurring).

175. See CASEBOoK, supra note 2, at 981-82; see also Schwegemann Bros. v. Calvert Distillers Corp., 341 U.S. 384, 395 (1951) (Jackson, J., concurring).

176. See CASEBOOK, supra note 2, at 1000; EsKRIDGE ET AL., supra note 173, at 312; GreENWALT, supra note 46, at 173; Eskridge, supra note 174, at 636-38; see also North Haven Bd. of Educ. v. Bell, 456 U.S. 512, 524-27 (1982).

177. Various sources have discussed the lesser authoritative status of legislative inaction and post-enactment history. See, e.g., Consumer Prod. Safety Comm'n v. GTE Sylvania, 447 U.S. 102, 117-18 (1980) (post-enactment history); CASEBOOK, supra note 2, at 1061, 1040 (legislative inaction and post-enactment history); John Grabow, Congressional Silence and the Search for 
are strong presumptions rather than hard rules: committee reports may be less reliable for certain reasons, ${ }^{178}$ and legislative inaction or post-enactment history may be more reliable in certain circumstances. ${ }^{179}$ of central importance, however, is that departures from the presumptions also have rational explanations grounded in the realities of Congress's lawmaking processes. ${ }^{180}$

Underlying these presumptions and exceptions is a standard for reliability based on how Congress's designated agents-or a bill's most influential supporters and opponents-fulfill their communicative function to their colleagues while navigating the challenges of a contingent political process. Courts are attempting to invoke the best evidence of "consensus within the legislature that can be routinely discerned" 181 or the evidence that is deemed to have been noticed, understood, and endorsed by a reasonable legislator. ${ }^{182}$ This reliability standard reflects a degree of imputation to what, paraphrasing Justice Scalia, "by a benign fiction [the judicial interpreter] assume[s] Congress always has in mind." 183 The imputation in turn rests on a hierarchy of resources that corresponds to the actual practices of congressional lawmaking.

Legislative Intent: A Venture into "Speculative Unrealities," 64 B.U. L. REv. 737 (1984) (legislative inaction and post-enactment history). On the lesser authority of floor statements by bill opponents and by supporters outside the enacting coalition, see, for example, EsKRIDGE ET AL., supra note 173, at 313 and GREENAWALT, supra note 46, at 173 (statements by bill opponents). See generally GREENAWALT, supra note 46, at 175 (listing a full hierarchy, ascribed to Eskridge); ESKRIDGE, supra note 174, at 636-40 (setting forth full hierarchy).

178. Committee reports are of limited value when the provision in dispute has been added to the bill as a floor amendment, or when the report's commentary on a provision is as inconclusive as the text itself. See CASEBOOK, supra note 2, at 982; see also Brudney, supra note 122, at 94-97 (discussing why committee reports accompanying omnibus budget reconciliation measures may often include untrustworthy commentary on isolated substantive law matters inserted for strategic purposes)

179. See CASEBOOK, supra note 2, at 1048-49 (discussing instances in which Court presumes that Congress has acquiesced in a high-profile or foundational interpretation by a federal court or an authoritative agency, especially where Congress reenacts or amends a statute without material changes to the provision in dispute); see also Faragher v. City of Boca Raton, 524 U.S. $775,792,804$ n.4 (1998) (applying this "reenactment rule" exception to ascribe meaning to legislative inaction); Lorillard v. Pons, 434 U.S. 575, 580-81 (1978) (explaining that when Congress reenacts a statute without change, it is presumed to be aware of and to adopt judicial interpretations of the statute that preceded reenactment); Mont. Wilderness Ass'n v. U.S. Forest Serv., 655 F.2d 951, 957 (9th Cir. 1981), cert. denied, 455 U.S. 989 (1982) (relying on postenactment legislative history because interpretation of earlier statute was drafted by Congress's designated experts on Conference Committee, it was explained to all members through floor statements accompanying Conference Report, and it was relied on by members when voting on the later bill); Brudney, supra note 122, at 90-91, 97-99 (discussing two instances in which postenactment legislative history was unusually reliable because it represented an integral part of the shared understanding reached by Congress as a whole).

180. See supra notes $178-179$.

181. ESKRIDGE ET AL., supra note 173, at 304.

182. See Brudney, supra note 122 , at $75-80$.

183. Green v. Bock Laundry Mach. Co., 490 U.S. 504, 528 (1989) (Scalia, J., concurring). 


\section{Agency Guidance}

Similarly, the Court has generated a fairly accessible hierarchy of resources regarding the explanatory directives issued by the executive branch about the meaning of inconclusive text. As with legislative history, the touchstone for this executive branch hierarchy is certain realities of the lawmaking process albeit from a different branch's vantage point. ${ }^{184}$ For agency rules or rulings that Congress meant to carry the force of law, judicial deference is at its highest level; as articulated in Chevron, the only question with respect to inconclusive text is whether the agency interpretation is based on a permissible construction of the statute. ${ }^{185}$ For rules or rulings where Congress did not authorize the agency to speak with the force of law, the Court confers less generous judicial deference; it considers multiple factors when evaluating the persuasiveness of agency judgments. ${ }^{186}$ Moreover, as summarized in Skidmore, within the universe of what is persuasive there are additional authoritative distinctions. ${ }^{187}$ Agency interpretations contemporaneous with enactment tend to be more respected than much later rulings, ${ }^{188}$ while agency interpretations conflicting with earlier directives are less respected than consistent interpretations. ${ }^{189}$ Broadly circulated agency interpretations are likely to garner more respect than private advisory opinions, ${ }^{190}$ and agency interpretations in highly technical or specialized areas tend to receive additional deference. ${ }^{191}$

184. See generally William N. Eskridge, Jr. \& Lauren E. Baer, The Continuum of Deference: Supreme Court Treatment of Agency Statutory Interpretations from Chevron to Hamdan, 96 GEO. L.J. 1085 (2008) (describing and classifying Court's varying degrees of respect for agency interpretations-from extremely strong deference in certain subject matter areas or with respect to agency interpretation of its own regulations, to relatively weak deference with regard to less formal or authoritative elaborations of a statutory scheme); Thomas W. Merrill \& Kristin E. Hickman, Chevron's Domain, 89 Geo. L.J. 833 (2001) (discussing stronger deference regime under Chevron doctrine and intermediate deference regime under Skidmore doctrine, and explaining what sources of congressional law justify each approach).

185. See Chevron U.S.A. Inc. v. Natural Res. Def. Council, Inc., 467 U.S. 837, 843-44 (1984); Merrill \& Hickman, supra note 184.

186. See United States v. Mead Corp., 533 U.S. 218, 228 (2001); Skidmore v. Swift \& Co., 323 U.S. 134, 139-40 (1944). See generally CASEBooK, supra note 2, at 1194-97, 1200-03, 1223-24 (discussing historical development of Court's agency deference standards).

187. See Skidmore, 323 U.S. at $\mathbf{1 4 0}$ (referencing “the thoroughness evident in [an agency's] consideration, the validity of its reasoning, its consistency with earlier and later pronouncements, and all those factors which give it power to persuade, if lacking power to control").

188. See, e.g., BankAmerica Corp. v. United States, 462 U.S. 122, 130-32 (1983); Sunray Mid-Continent Oil Co. v. FPC, 364 U.S. 137, 154 (1960). See generally Alfred C. AMAN, JR. \& William T. Mayton, Administrative Law 496-97 (2d ed. 2001).

189. See, e.g., General Electric Co. v. Gilbert, 429 U.S. 125, 142-43 (1976); Saxbe v. Bustos, 419 U.S. 65, 73 (1974). See generally AMAN \& MAYTON, supra note 188, at 498-99.

190. See, e.g., Christensen v. Harris County, 529 U.S. 576, 586-88 (2000) (rejecting deference to private Department of Labor opinion letter). See generally AMAN \& MAYTON, supra note 188 , at 502 .

191. See, e.g., Bragdon v. Abbott 524 U.S. 624, 642-45 (1998) (deferring to expert medical judgment). See generally Charles H. Koch, 3 Administrative LaW and Practice 115 (2d ed. 
These distinctions are not always observed - a recent empirical study of Court practice since Chevron suggests a broad range of deference schemes resulting in reduced levels of certainty. ${ }^{192}$ Notwithstanding such variations, however, reliance on agency guidance continues to be situated in a larger prioritized context. ${ }^{193}$ Departures from the deference standards are explained in relatively objective terms as well-by reference to the agency's own failure to act consistently or to offer adequate reasons or respond to prior judicial invitations. ${ }^{194}$ Further, as was true for the Court's rubric on legislative history, the underlying framework is itself grounded in certain lawmaking realitiessuch as whether Congress has authorized the agency to speak with the force of law, how well the agency's conduct conforms to the essentials of due process, or the extent to which agency action rests on special subject matter expertise. Agencies garner respect and deference based on this framework in a reasonably consistent and broadly predictable way.

\section{Canons}

In contrast to legislative history and agency guidance, the Court has not developed an architecture of authoritative priorities for the canons. The absence of such a framework is due in large measure to the inherent imprecisions of the English language. Because words are "inexact symbols" 195 of meaning, they often cannot be properly understood without reference to the context or community from which they emerge. ${ }^{196}$ Thus, for instance, whether a party's position in court is "substantially justified"197 or a plant closing is "reasonably foreseeable" 198 are not matters that can be resolved solely by reliance on ordinary meaning or semantic analysis.

Sixty years ago, Professor Karl Llewellyn succinctly described how the canons so often point in opposite directions with respect to the ambiguities-

1997).

192. See Eskridge \& Baer, supra note 184; see also Thomas J. Miles \& Cass R. Sunstein, Do Judges Make Regulatory Policy? An Empirical Investigation of Chevron, 73 U. CHI. L. REv. 823, 831-47 (2006) (demonstrating that Court's invocation of Chevron doctrine from 1989 to 2005 reflects Justices' ideological preferences when deciding whether to defer to agency rulings).

193. See Eskridge \& Baer, supra note 184; Merrill \& Hickman, supra note 184.

194. See, e.g., Avecor, Inc. v. NLRB 931 F.2d 924, $937-38$ (D.C. Cir. 1991); Montgomery Ward \& Co. v. NLRB, 904 F.2d 1156, 1159 (7th Cir. 1990) (referencing agency's failure to offer adequate reasons); see also Lee Lumber v. NLRB, 117 F.3d 1454, 1462 (D.C. Cir. 1997) (referencing agency's failure to respond to prior judicial invitations).

195. Felix Frankfurter, Some Reflections on the Reading of Statutes, 47 Colum. L. Rev. 527,528 (1947).

196. See Frederick Schauer, Statutory Construction and the Coordinating Function of Plain Meaning, 1990 SuP. CT. Rev. 231, 251 \& n.82 (1990).

197. Equal Access to Justice Act, 28 U.S.C. § 2412(d) (2006); see Pierce v. Underwood, 487 U.S. 552 (1988).

198. Worker Adjustment and Retraining Notification Act, 29 U.S.C. $\S 2102(\mathrm{~b})(2)(\mathrm{A})$ (2006); see Pena v. Am. Meat Packing Co., 362 F.3d 418 (7th Cir. 2004). 
and also the gaps-that abound in the texts enacted by Congress. ${ }^{199}$ In the ensuing decades, many scholars and judges have come to recognize that efforts to promote a canonical framework for interpreting statutes rest on the beguiling yet false assumptions that Congress regularly strives for structural coherence and linguistic consistency when drafting laws, and that such coherence and consistency can be readily discerned in its final products. ${ }^{200}$ As Frickey and others have observed, the congressional drafting process is politically rather than linguistically oriented. ${ }^{201}$ And the Court's decisions provide ample evidence that Congress's complex statutory schemes-revised and extended over many years - produce linguistic residues, redactions, and repetitions that generate reasonable divergent understandings of how canons such as the whole act rule or expressio unius should apply, ${ }^{202}$ or of whether one verb in a sequence of verbs should be construed as distinctive to "avoid surplusage" or as indistinct to comport with noscitur a sociis. ${ }^{203}$

Nor do the scores of judicial policy preferences set forth in substantive canons and deftly catalogued by Frickey lend themselves to the development of a systemic framework or design. Certain substantive canons are rather openended while others convey a more precise prescriptive message. ${ }^{204}$ Some canons are based on generally applicable legal principles while others are grounded in specific subject matter policies. ${ }^{205}$ Courts that promote this array of

199. See Karl L. Llewellyn, Remarks on the Theory of Appellate Decision and the Rules or Canons About How Statutes Are to Be Construed, 3 VAND. L. REv. 395, 401-06 (1950).

200. See, e.g., Edward L. Rubin, Modern Statutes, Loose Canons and the Limits of Practical Reason: A Response to Farber and Ross, 45 VAND L. Rev. 579, 580 (1992) (critical of presumption "that a statute is primarily a linguistic artifact"); Buzbee, supra note 86, at 234 (critical of counterfactual assumptions about omniscient legislators in drafting process); see also POSNER, supra note 115 , at $277-82$ (describing as "wholly unrealistic" the assumption that Congress is omniscient in its linguistic drafting process).

201. See supra notes 81-82 and accompanying text (discussing Frickey's observations); supra notes 165-167 and accompanying text (discussing observations by other scholars).

202. See, e.g., Mackey v. Lanier Collection Agency, 486 U.S. 825, 836-37, 842-43 (1988) (disagreement between White, J., and Kennedy, J., over how whole act rule should apply); Church of the Holy Trinity v. United States, 143 U.S. 457, 458-59, 462-65 (1892) (acknowledging direct conflict between expressio unius and whole act rule when construing 1885 Immigration Act). See generally Brudney \& Ditslear, supra note 38, at 103-05 (discussing systemic malleability of language canons).

203. See Babbitt v. Sweet Home Chapter of Cmtys. for a Great Or., 515 U.S. 687, 697-98, 702, 719-21 (1995) (disagreement between Stevens \& Scalia, JJ., as to whether whole act rule or noscitur a sociis controls); see also Lehman v. Nakshian, 453 U.S. 156, 162-63, 177-78 (1981) (disagreement between Stewart \& Brennan, JJ., as to whether expressio unius or in pari materia should control meaning of text).

204. See Brudney \& Ditslear, supra note 38, at 105-06 (contrasting open-ended canons like constitutional avoidance, and presumption against implied repeals, which offer only vague guidance to Congress, with specific canons like presumptions against asserting extraterritorial jurisdiction or abrogating states' Eleventh Amendment immunity).

205. See Brudney \& Ditslear, supra note 55, at 1268 (contrasting generally applicable legal principles such as rules disfavoring federal preemption of core state functions or implied waivers of sovereign immunity with specific subject matter policies such as presumptions favoring labor 
substantive values and preferences inevitably waver as to whether the preferences should be applied as tiebreakers, presumptions, or clear statement rules. ${ }^{206}$

In theory, a coherent architecture could be developed by specifying certain canons as taking automatic or presumptive precedence over others, or by providing safe harbor-type formulations for what satisfies a particular language or substantive canon. ${ }^{207}$ Unlike priorities developed with respect to legislative history and agency guidance, however, these judgments would not be grounded in the realities of how federal laws are enacted or implemented. Moreover, although another linguistic resource-the dictionary -includes certain arguably objective indicia of authoritative priority, ${ }^{208}$ canons as maxims created by courts and invoked for their own use lack such extrinsic or objective indicators. The Court's failure to develop any interpretive rubric for prioritizing or ordering its reliance on different canons may well stem from an implicit understanding that such a creation would be both arbitrary and unproductive.

My reservations about objectivity are not meant to suggest that canons are incapable of situationally valuable application. Moreover, beyond specific applications, the Court may rely on canons for somewhat different functions in distinct subject areas ${ }^{209}$ and individual Justices may place varying emphasis on particular canons based on how they wish to promote dialogue with the other branches. $^{210}$ Still, the absence of any broad-based interpretive rubric or framework means the canons are unable to establish an adequately objective presence. Accordingly, although some judicial discretion is essential and indeed salutary for the interpretive enterprise, judges who regularly rely on the canons have license to employ a systemic kind of discretion, in contrast to

arbitration or disfavoring implied tax exemptions).

206. See Brudney \& Ditslear, supra note 38, at 106 (discussing cases); Note, supra note 66, at 1612-13 (discussing Court's evenly divided record on cases involving federal preemption canon from 1983 to 2004 ).

207. Professor Rosenkranz suggests that Congress might establish these canonical priorities legislatively (see Rosenkranz, supra note 121, at 2148-50), but comparable options are presumably open to the Court.

208. See generally Samuel A. Thumma \& Jefferey L. Kirchmeier, The Lexicon Has Become a Fortress: The United States Supreme Court's Use of Dictionaries, 47 BuFF. L. REV. 227, 267-76 (1999) (discussing Court's need to choose between general usage and more technical dictionaries; between dictionaries produced by different "authors"; between different editions of the same dictionary; and between different-generally prioritized-definitions of the word in question). Admittedly, the Justices have been criticized for a largely subjective and often chaotic reliance on dictionaries since usage expanded in the 1980s. See id. at 264-76; Note, Looking It Up: Dictionaries and Statutory Interpretation, 107 HARv. L. Rev. 1437, 1445-49 (2007). Still, the Court could establish strong presumptions with respect to dictionary usage-e.g., announcing a preference for Webster's International, for editions in place when the litigation arose (as opposed to when the law was enacted), and for a word's primary definition (as opposed to secondary or tertiary definitions). See Rosenkranz, supra note 121, at 2147-48 (proposing that Congress adopt a similar approach).

209. See Brudney \& Ditslear, supra note 55, at 1266-70, 1294-1300 (tax law versus workplace law).

210. See Brudney, supra note 120, at 913-22 (discussing approach of Justice Ginsburg). 
judges who regularly invoke legislative history or agency deference. We should worry about this systemic discretion, especially given the efforts of some judges and scholars to enshrine the canons as an institutionally objective interpretive asset. Rather than enshrine them, we ought to limit the untethered role played by the canons, making them interstitial in comparison to the more anchored interpretive assets.

\section{CONCLUSION}

No one has done more to contribute to a nuanced understanding of the canons than Phil Frickey. His critical perspective and measured justifications convey both an appreciation for the canons' value in particular settings and a skepticism regarding claims that they deserve elevated status. In addition, Frickey's insights have focused attention on the canons' institutional role in promoting policies favored by the judicial branch-notably an interest in encouraging more efficient legislative drafting and in protecting what the Court views as underenforced constitutional norms.

This Essay has extended Frickey's institutional perspective by identifying particular concerns about the canons in contrast to interpretive assets produced by the other two branches. Although not the only recent effort to suggest a more limited role for the canons, ${ }^{211}$ the Essay does so by examining certain normative attributes associated especially with legislative history but not with the canons. ${ }^{212}$ Some readers may question the failure to address potentially relevant criticism of legislative history - that it is systemically unreliable because opportunistically created by members of Congress or their staffs or because selectively invoked by judges to help justify their preferred policy results. ${ }^{213}$ These criticisms deserve an in-depth response, but I have offered that response in previous articles ${ }^{214}$ and others have done so as well. ${ }^{215}$ I have

211. See ElHAUGE, supra note 12, at 9-12, 151-52 (contending that canons occupy a thirdtier position as preference-eliciting default rules). For critical perspective on Elhauge, see Garrett, supra note 75 , at $2124-28$.

212. Cf. Thomas Merrill, Textualism and the Chevron Doctrine, 72 WASH. U. L.Q. 351, 372 (1994) (critical of textualism as an exercise in judicial ingenuity, in contrast to the more grounded archaeological approach taken by intentionalism).

213. On the critique of legislative history as strategically planted or opportunistically created, see, for example, Eskridge, supra note 174, at 643-44; Barry R. Weingast \& William J. Marshall, The Industrial Organization of Congress; or Why Legislators, Like Firms, Are Not Organized as Markets, 96 J. PoL. ECON. 132, 148-52 (1988); Blanchard v. Bergeron, 489 U.S. 87, 99 (1989) (Scalia, J., concurring). On the critique of legislative history as selectively and subjectively invoked by judges, see, for example, GreEnAwALT, supra note 46, at 181 and Kozinski, supra note 116 , at 813 .

214. See, e.g., Brudney, supra note 122, at 47-60 (explaining why, notwithstanding anecdotal exceptions, legislative history is neither corruptly produced nor unrepresentative of the larger body); Brudney \& Ditslear, supra note 159, at 131-60 (demonstrating empirically that for the universe of statutory workplace law decisions between 1969 and 2006, liberal Justices did not invoke legislative history to favor their own policy preferences).

215. See, e.g., George A. Costello, Average Voting Members and Other "Benign Fictions": 
resisted the temptation to reprise or highlight those responsive positions given the prescribed limitations of the Essay format.

For nearly two decades, textualist judges and scholars have effectively framed the constitutional and policy debate about statutory interpretation. It may now be time for the terms of that debate to shift toward greater respect for the role of interpretive resources generated by the political branches.

The Relative Reliability of Committee Reports, Floor Debates, and Other Sources of Legislative History, 1990 Duke L.J. 39, 60-73; Eskridge, supra note 174, at 636-40; Charles Tiefer, The Reconceptualization of Legislative History in the Supreme Court, 2000 WIS. L. REV. 205, 264-70 (2000). 
